\title{
Gametogenesis in the Sugarcane Borer Moth, Diatraea saccharalis (F.) (Crambidae)
}

\section{Niilo Virklii}

\section{INTRODUCTION}

Butterflies and moths have long served as objects for cytological and cytogenetical studies. Much of our knowledge on the cytology of hybrids is directly based on the early observations made by Federley in Lepidoptera, and intersexuality and parthenogenesis were widely studied cytologically in lepidopteran objects by Seiler, Goldschmidt, and Federley, to mention only three successful students of the order. The total number of species studied cytologically up to 1956 is listed by Makino $(59 \text { and } 60)^{2}$ and is near to 400 . The results accumulated permit the following general characterization of the lepidopteran cytology:

1. The chromosome number is high. While many large insect orders widely possess 2 n numbers like 8 or 12 (Diptera), 14 (Hemiptera), or 20 (Coleoptera), the diploid number in Lepidoptera usually falls around 60 .

2. The chromosomes are short. In the reduction metaphase of meiosis the bivalents look like rounded dots from the polar view.

3. The chromosomes have a diffuse centromere (88). This means that chromosome fragments, naturally or artificially arisen, are capable of surviving like intact chromosomes. Some experimental data support this postulate in Lepidoptera (31).

4. Meiosis is prereductional in the male, postreductional in the female (88). This means that in oogenesis the bivalents divide along the newly (in diplotene) formed chromatid split, and the "half bivalents" undergo a reduction in the second meiotic division.

5. The female is the heterogametic sex. In three animal groups-all are incidentally flyers-Aves, Lepidoptera, and Trichoptera, the female is found to possess the une(pual pair of sex chromosomes (usually $\mathrm{X}$ and Y). In most animals with sex chromosomes, male heterogamety is the rule.

Regarding the family Crambidae, to which our present subject, Diatraea saccharalis, belongs, there are no cytological data available. There are some accounts about the extensive family Pyralidae, in which Crambidac was formerly included as a subfamily. Kernewitz (48), logg (32), and Wagner (96) studied the flour moth Ephestia kuchniella. Their data are contradictory; $\mathrm{n}=29$ was reported by Kernewitz, whereas the later authors reported

1 Assistant Cytogeneticist, Agricultural Experiment Station, University of Puerto Rico, Río Piedras, P.R.

2 Italic numbers in parentheses refer to Litorature Ciled. pp. 133-7. 
$\mathrm{n}=30 . \mathrm{N}=29$ was found also in a Japanese species, Chilo simplex, by Kurihara (51). The chromosomes of these two pyralids are typically lepidopteran in number and in shape.

The purpose of the cytological study of Diatraea saccharalis is threefold: 1, To describe the chromosome relationships in a species and a family cytologically unknown up to now; 2 , to check the initiation and course of gametogenesis throughout the life cycle, in order to provide useful data for sterilization experiments through the use of radiation; 3, to study the cytological effects of radiation on the gametogenesis. Results from the first two of these studies are published herein; the third will be reported later.

\section{MATERIAL AND METHODS}

All material came from the Department of Entomology of this Station, where Diatraea saccharalis is reared for radiation experiments. Indebtedness to Dr. L. F. Martorell, Head of the Department of Entomology, and to Mr. S. Medina Gaud, Assistant Entomologist, for the delivery of the material, and for other help also, is expressed here.

\section{EGGS}

The females were allowed to oviposite on waxy, thin paper, from which the egg clusters can be removed easily by folding the paper and using a scalpel. The clusters were fixed overnight in Carnoy, 6 parts absolute alcohol to 3 parts chloroform and 1 part glacial acetic acid, embedded in paraffin by the usual butanol method, and sectioned to $15 \mu$.

\section{L.ARVAE}

The larvae were cut with scissors from behind the caudalmost pair of thoracal legs, and the abdominal half was immersed in Bouin-Allen-Bauer fixative for $2+$ hours. 'The procedure was the same as with eggs after fixation and dehydration.

\section{PLPAE}

The abdomens of the pupae were opened dorsally with sharp scissors and the wound was kept open with insect pins fixed in the borders. A drop of liahle-Smith fixative was introduced into the wound. The testes, fused to one single body, form the only clearly structured organ in the histolytic contents of the male pupal abdomen, and can be found easily, especially after the fixative has been working 1 minute or so. It is adrisable to remove the abdominal tip of the pupa before the dorsal cut is made, because the introduction of the scissors into the pupa may cause a partial outburst of the contents and rupture of the testes. After 1 or 2 minutes of fixing the testes were transferred and converted into small pieres on an albuminized 
slide, heated over flame, and squashed between the slide and cover slip with careful thumb pressure. The squashes were studied under phase-contrast optics, and the best ones were stained, and made permanent by the usual dehydration method in alcohol series. Sectioned preparations of the total abdomen of the pupae of both sexes were also made, using the same procedure as for the larvae.

\section{ADULTS}

The abdomens of adults were separated from the bodies and handled in the same way as pupae, except that the section method prevailed.

As stain, lactic aceto-orceine (15), leucobasic fuchsine, or Heidenhain's haematoxylin were used for all sectioned preparations, the two former also for permanent squashes. Heidenhain's haematoxylin produces excellent results, but could be used very little, for lack of time.

The fixations were not made at regular age intervals. The material was prepared and studied in the order of delivery, and different stages and ages were checked until a clear idea of the whole process of the gametogenesis was obtained.

An Ortholux Leitz microscope was used for the observations and, for photomicrography, the Makam Leitz camera, together with Ortholux. Either Kodak Ortho Contrast Process film or Dupont Cronar High Speed Pan film was used as negative material. Magnification of the pictures is given later.

\section{OBSERVATIONS}

\section{EARLY STAGES}

\section{Eggs}

Older ovarial or recently posited eggs are supposed to show the female meiotic divisions in the Lepidoptera. Oviposition of Diatraea saccharalis occurred during the night only. The female is very intolerant of disturbance and stops ovipositing easily. ${ }^{3}$ For this reason recently oviposited eggs were not collected. At 8 to 9 a.m. the eggs already contain an embryo of approximately 16 to 64 cells (fig. 1). In this stage most of the nuclei are still freely floating in the yolk or may have just started aggregating themselves to form the cleavage center. Synchronous mitoses were encountered abundantly, but chromosome counts were not attempted.

The shape of the eggs is curious; they are flat, scuuamate, and strongly joined together by their shells (chorion) to form clusters of varying size.

No attempt was made to follow the early formation of gonads from the germ band.

${ }^{3}$ Medina Gaud, personal communication 


\section{Larvae 1 to 4 Days Old}

In the first 3 days of larval life the germ-line cells do not form any easily distinguishable organ. At the fourth day a small paired gonad was found, located dorsally and in contact with the mesoderm. From this age on the

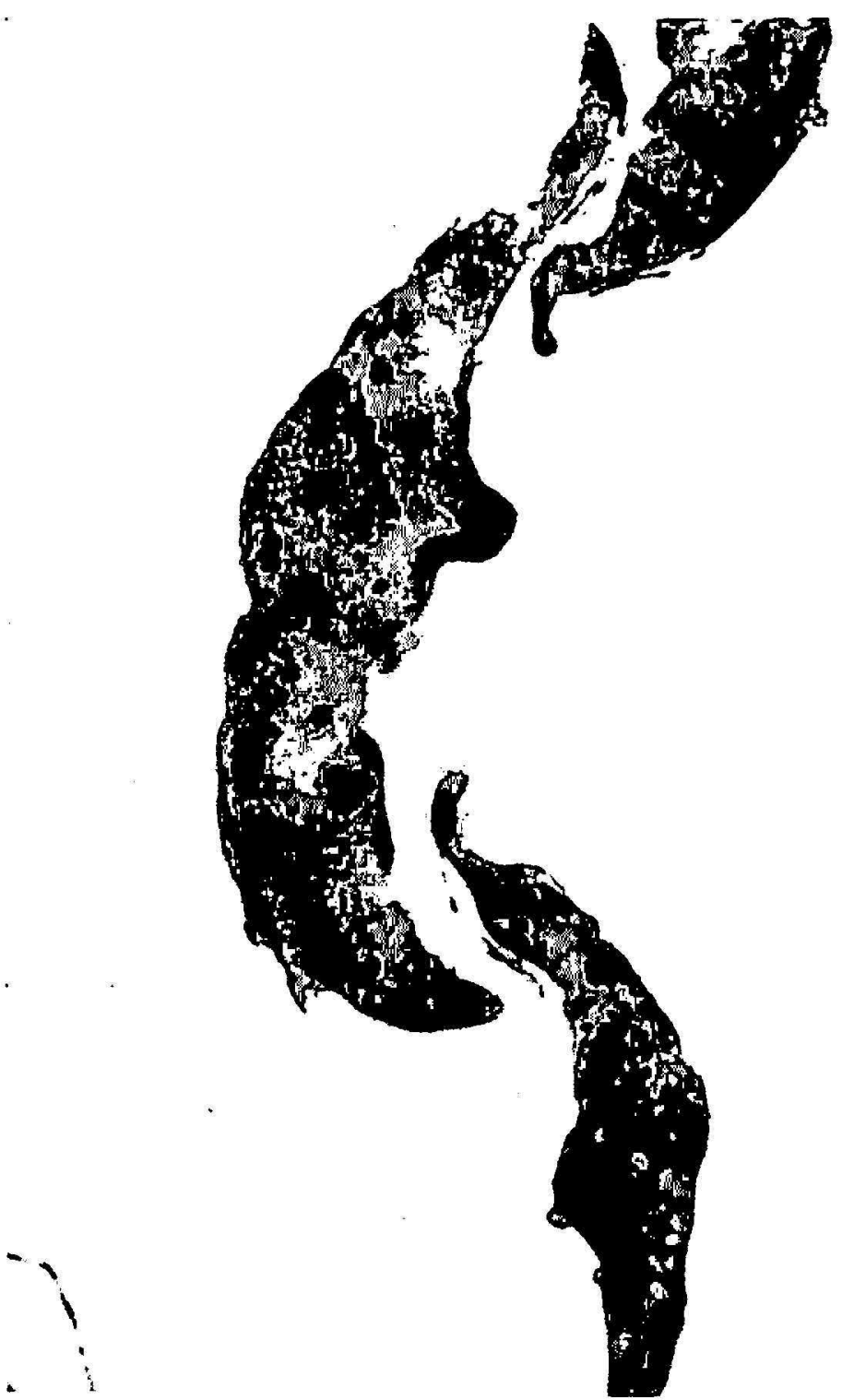

Fig. 1.-Part of an egg cluster in the morning following oviposition. Dark dots are synchronously dividing, prophasic cleavage nuclei still floating freely in the yolk. Magnification $175 \times$. Sectioned preparation.

testes begin to grow rapidly, whereas the development of the ovaries is very slow.

\section{DEVELOPMENT OF TESTES, AND SPERMATOGENESIS}

\section{Larrae 5 Days Old}

The growing testes are five-lobed and still separate. They contain spermatogonia, of which some are dividing. There are approximately 30 small chromosomes in the gonial mitoses. 


\section{Larvae 6 Days Old}

A distinct but considerable thin membrane lines the testes which are much grown. The socalled apical or Verson's cell $(40)$ is visible in the apex of each testis follicle. The first young spermatocytes are seen in the basal portion of the follicle opposite the Verson's cell.

\section{Larvae 7 to 9 Days Old}

One-third to two-thirds of the germ-line cells of the follicles have transformed, beginning from the basal end, into young spermatocytes of first order. The gonads are still in contact with the general mesoderm (fig. 2).

\section{Larvae 10 to 11 Days Old}

Meiosis has generally proceeded up to pachytene or diplotene, but one spermatocyst in telophase I was seen already in an 11-day-old larva. Verson's cell was apparently still functioning (fig. 3) and one-third, or slightly less, of the contents of the follicles remained as spermatogonia. The somatic ducts of the testes were forming.

\section{Larrae 15 Days Old}

The outer membrane of the testis was in its thickest stadium (fig. 4 ). The relative amount of spermatogonia had not diminished much. All stages of the spermatogenesis were present, including the spermiohistogenesis and a few spermatozoon bundles also.

There are 17 bivalents in the plates of the first meiotic division. The bivalents are small and dotlike from the polar view, as the lepidopteran bivalents usually are. Interestingly, the profile views showed broad, or almost double, spindle fibres on every chromosome, a phenomenon attributed to diffuse centromeres (88) (fig. 5,A).

No heteromorphous bivalent was seen, the species being undoubtedly female-heterogametic. The anaphase of the first division is perfect, resulting in 17 chromosomes in the plate of the second division (fig. 5,B).

\section{Larrae 15 to 33 Days Old}

The meiosis and turning of spermatogonia into spermatocytes continues. At the age of 3:3 days, when the larva is ready to pupate, there are still spermatogonia in the germarium, and cysts of spermatocytes of first order, most of the latter in prophase. Different stages of spermiohistogenesis fill the main portion of the follicle. At from 15 to $33: 3$ days the membrane of the testes becomes much thinner (fig. (6).

\section{Pupae 1 Day Old}

Study of the testis contents gives the impression that control of the normal process of meiosis is being lost. There are still first metaphases with 


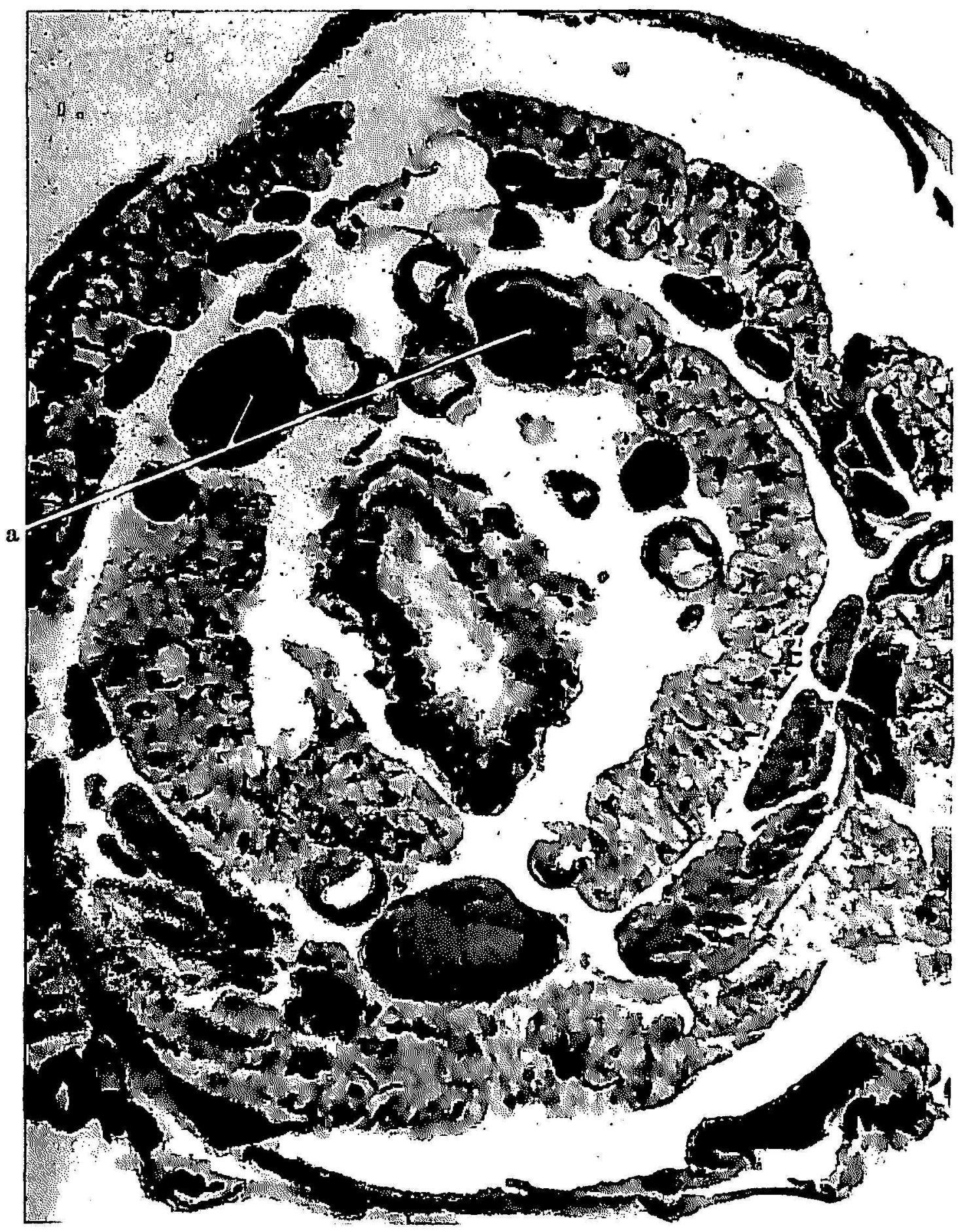

Frg. 2.-Transversal section of a 8-day-old larva, showing the gonads (a) st ill in contact with the main mesoderm. Magnification $200 \times$.

normal bivalent numbers and first anaphases that seem to proceed with regularity. But there are also many spermatocysts, or single spermatocytes in a normal cyst, where there is no conjugation, and anaphases of such speratocytes leading to uneven ('hromosome numbers. Some spermatogonia still remain in the apical portion of the follicle. 


\section{Pupae 2 to 6 Days Old}

Asynapsis of the homologous chromosomes is now the rule. As soon as the chromosomes can be separately counted with some certainty, e.g. from

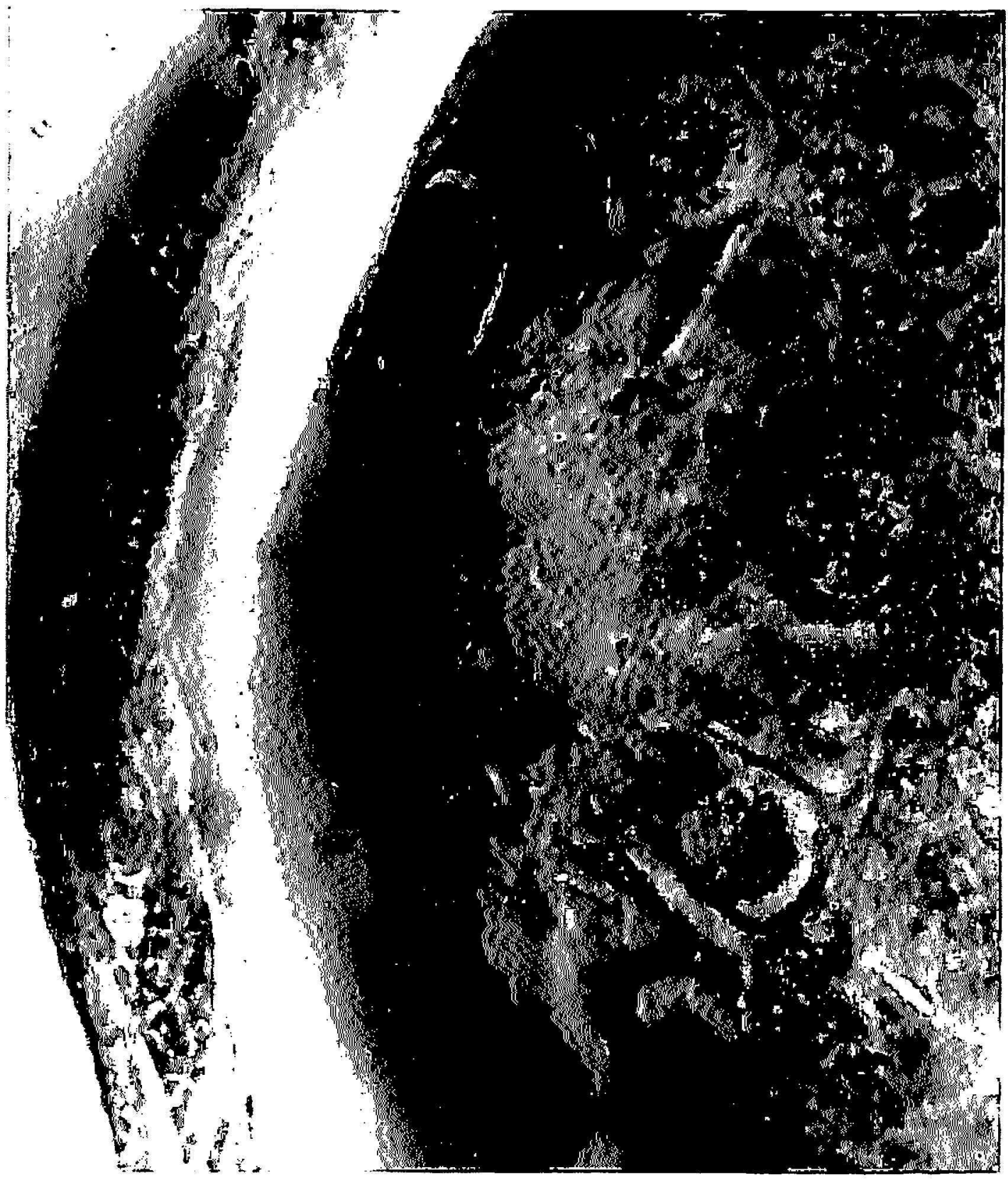

Fig. 3.-Apical or Verson's eell in the distal tip of at test is follicle of a larva 11 days old. Primordial spermatogonia stay in plasmal connection with the apical cell. Magnification $2200 \times$. Feetioned preparation.

diakinesis on, the spermatocytes of the first order show :3t univalent chromosomes. They are less condensed than in normal cells (fig. $7, A$ ). Constrictions are not scen.

There is a residual pairing tendency which causes formation of a few pseudobivalents per cell. These pseudobivalents were just aggregations 


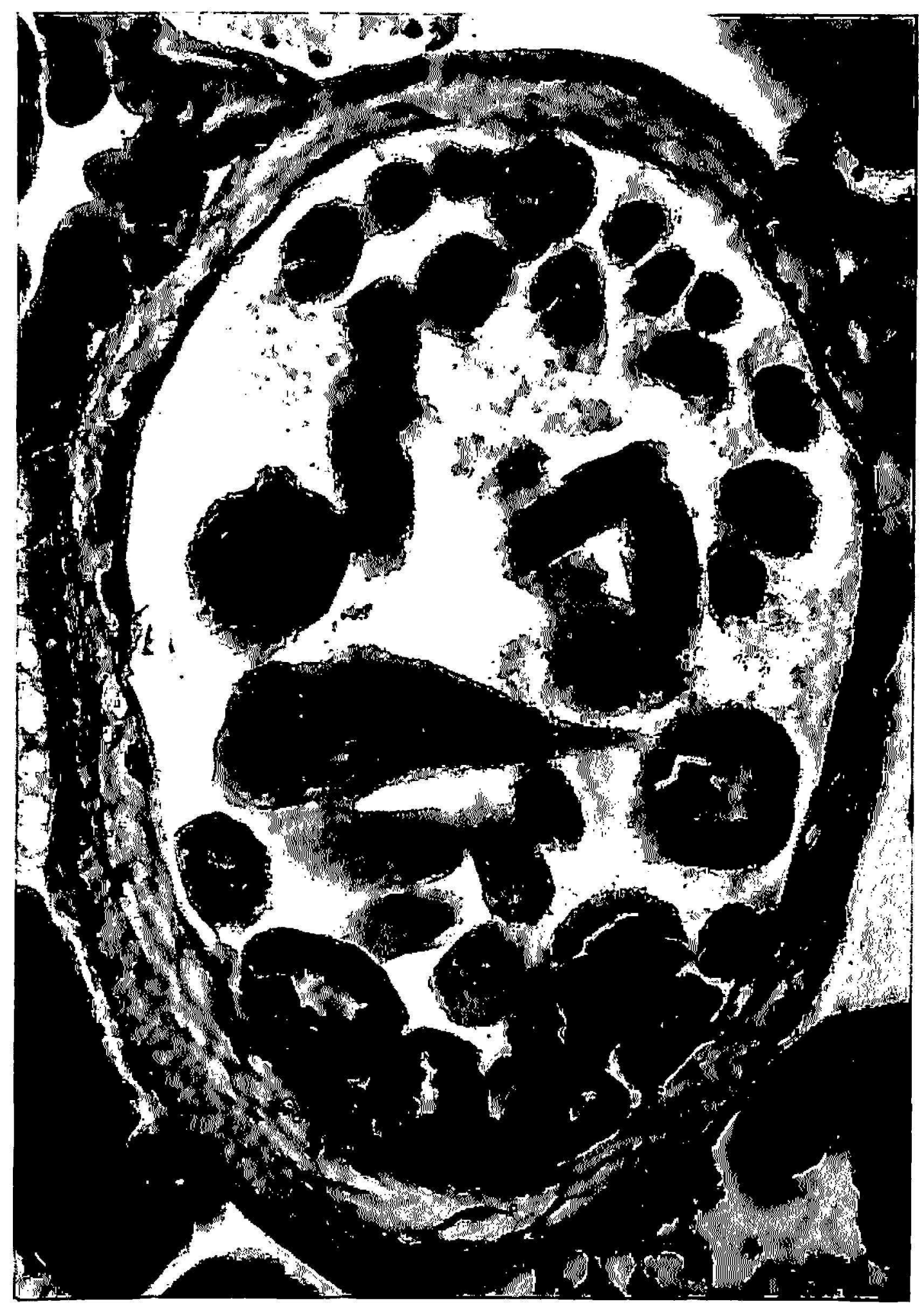

Fig. 4. - Section of a test is follicle of a larva 15 days old. Spermiohistogenesis and growing spermatocytes $I$. Note the thickness of the follicle membrane as compared with fig. 6. Magnification $200 \times$. 


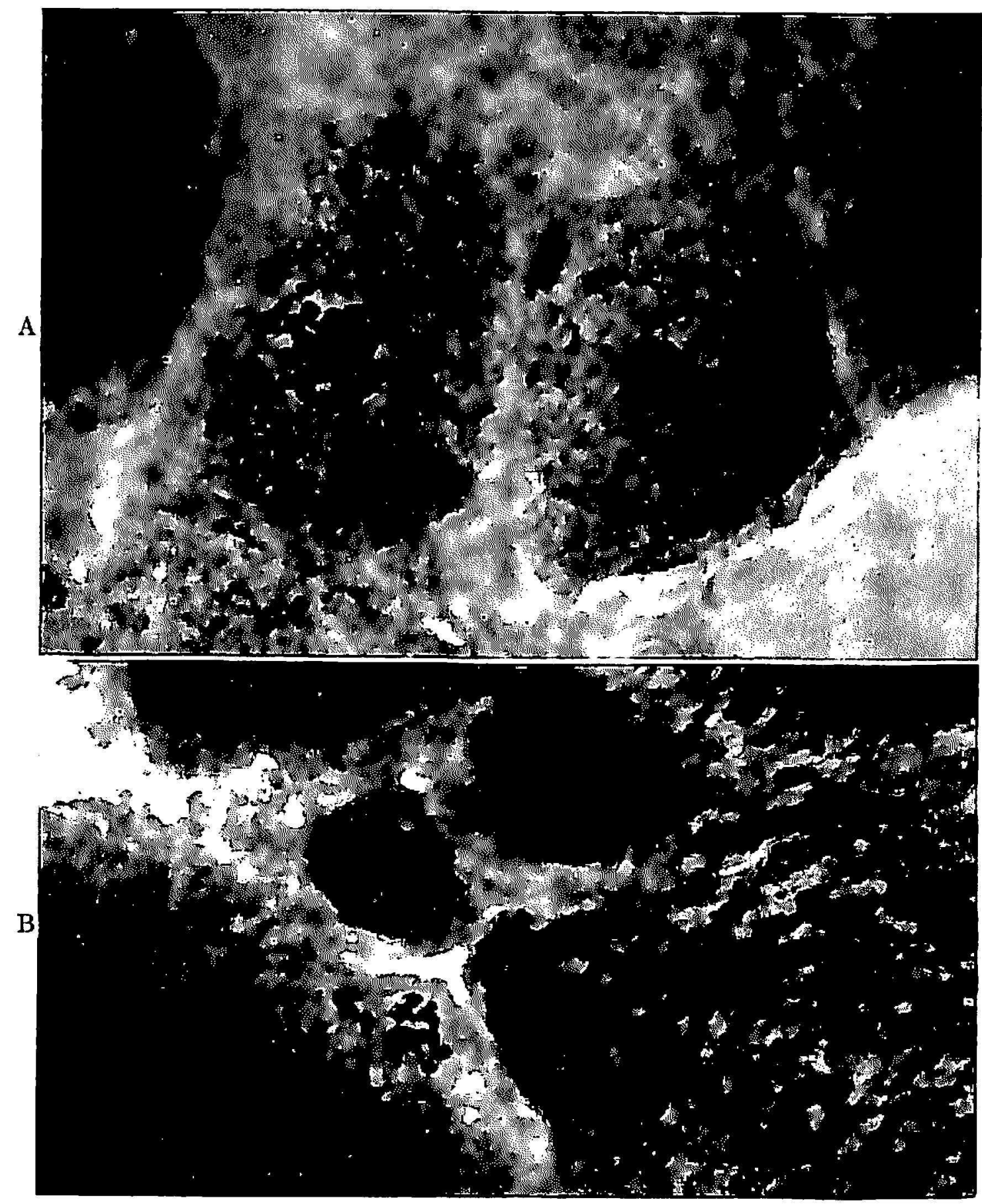

Frg. 5.-Spermatocytes I and II of a larva of 15 days of age: A, At left polar view of metaphase I showing 17 bivalents; at right profile view of the same showing broad or double-spindle fibres. B, Anaphase II with 17 chromosomes. Magnification $2200 \times$ Sectioned preparations. 
without chiasma formation, and of a bypassing nature. In one prometaphasic cyst wherein the number of chromosomes could be determined in 23 cells the variation was as follows:

$\begin{array}{lrrrrrr}\text { Number } & 28 & 30 & 31 & 32 & 33 & 34 \\ \text { Frequency } & 1 & 2 & 4 & 6 & 1 & 9\end{array}$

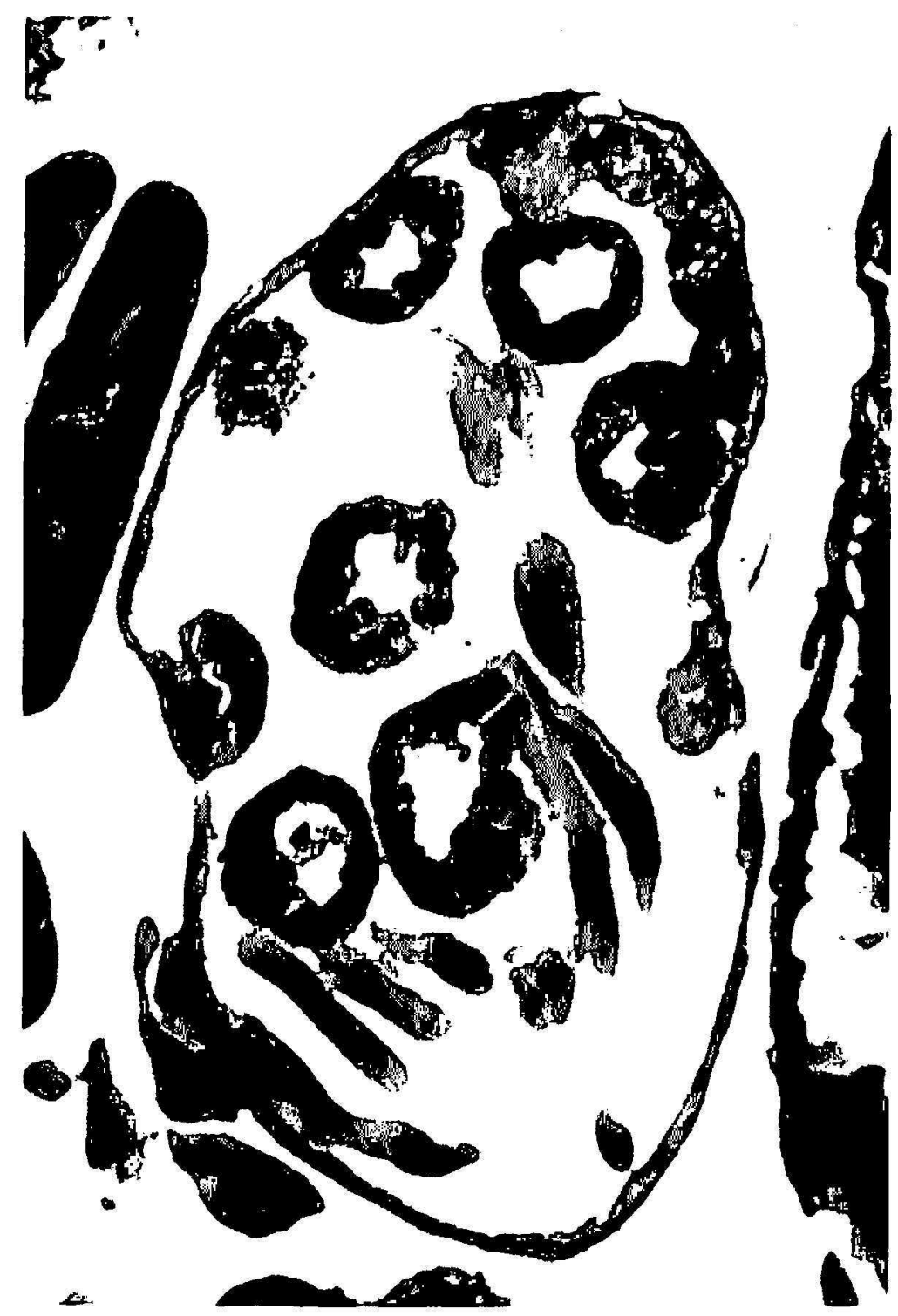

FIG. 6.- Tection of a test is follicle of a larva 33 days old. Spermiohistogenesis and growing spermatocytes $I$. Note the thinness of the follicle membrane as compared with fig. 4. Magnification $200 \times$.

In this cyst, cases with two to three pseudobivalents were almost as common as the romplete asynapsis. A first metaphase wherein all chromosomes formed hivalents, oddly standing erect in the plate (fig. $7, \mathrm{~B}, \mathrm{C}$ ), was encountered twice. There was a longitudinal split clearly visible in most of these exreptional bivalents. These formations rould be the results of a 
recent nonchiasmate pairing of homologues, or the split might represent the diplotenic split. In the light of earlier observations on diffuse centromeres (88) and apyrenous asynapsis (73), the latter alternative looks more probable. Further "independization" of the chromatids would probably cause postreduction, as is the rule in the female meiosis of lepidopters.
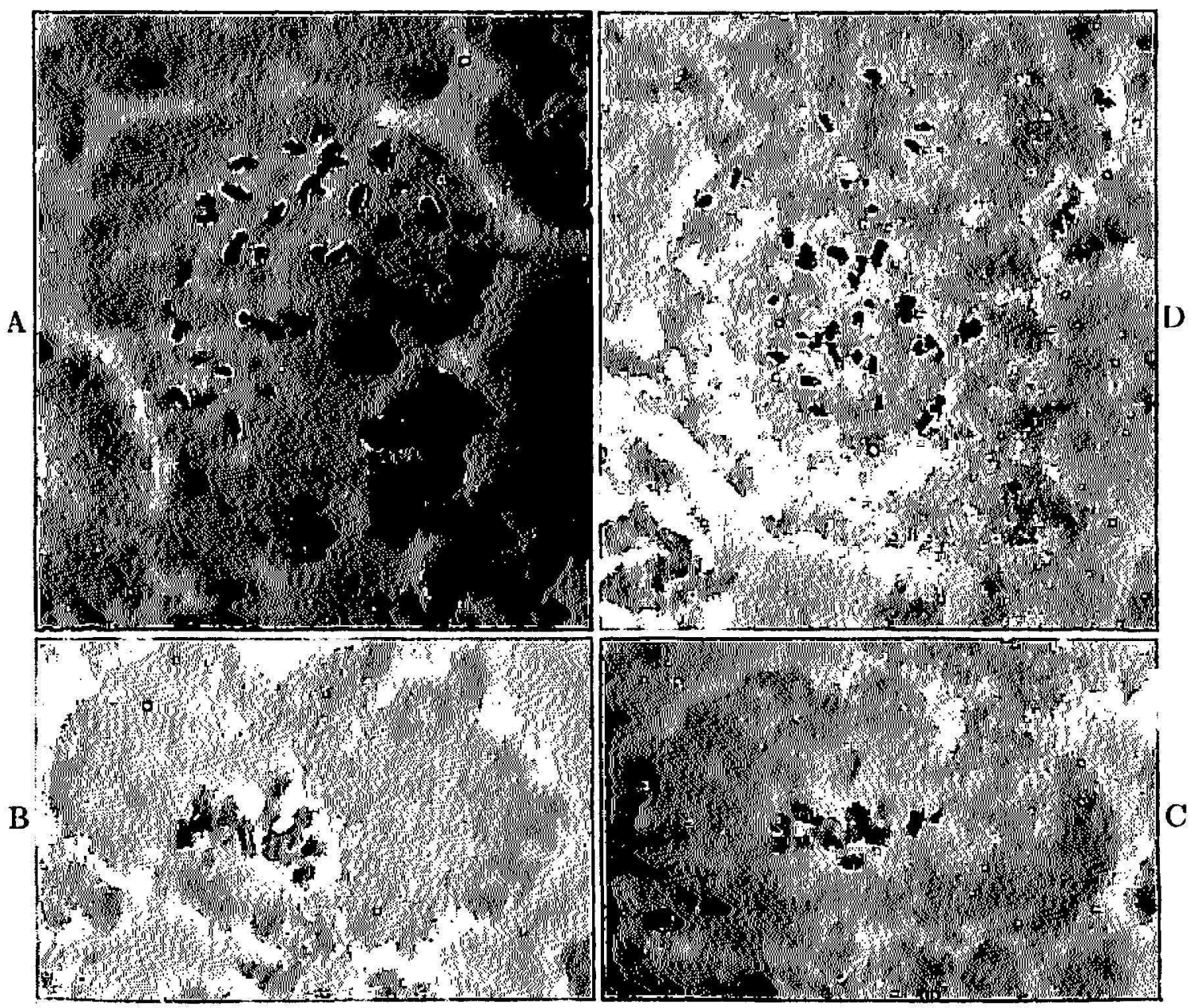

FIG. 7.-Asynaptic spermatogenesis in pupa: A, 3t univalents in prometaphase $I$. $B$ and $C$, Nearly 17 hivalents in two exceptional first metaphases of an asynaptic cyst. The clear longitudinal split of the bivalents presumably represents the split which appears in diplotene. D, Stage representing metaphase I. Short pairing or coörientation of chromosomes in the middle of the cell. Magnification $1500 \times$. Squash preparations.

In the vast majority of cases the chromosomes seem to enter the metaphase as single bodies. Just prior to the first anaphase, however, a short contact pairing occurs, although not regularly. Perhaps there is sometimes only a moment of coorientation of the homologues. Classic metaphase plates are never formed in these dividions, and the most metaphaselike cases look like mixed meta- and anaphases, where some of the chromosomes are just pairing at the e(puator, others going to the poles (fig. $7, \mathrm{D})$ ). That 
il
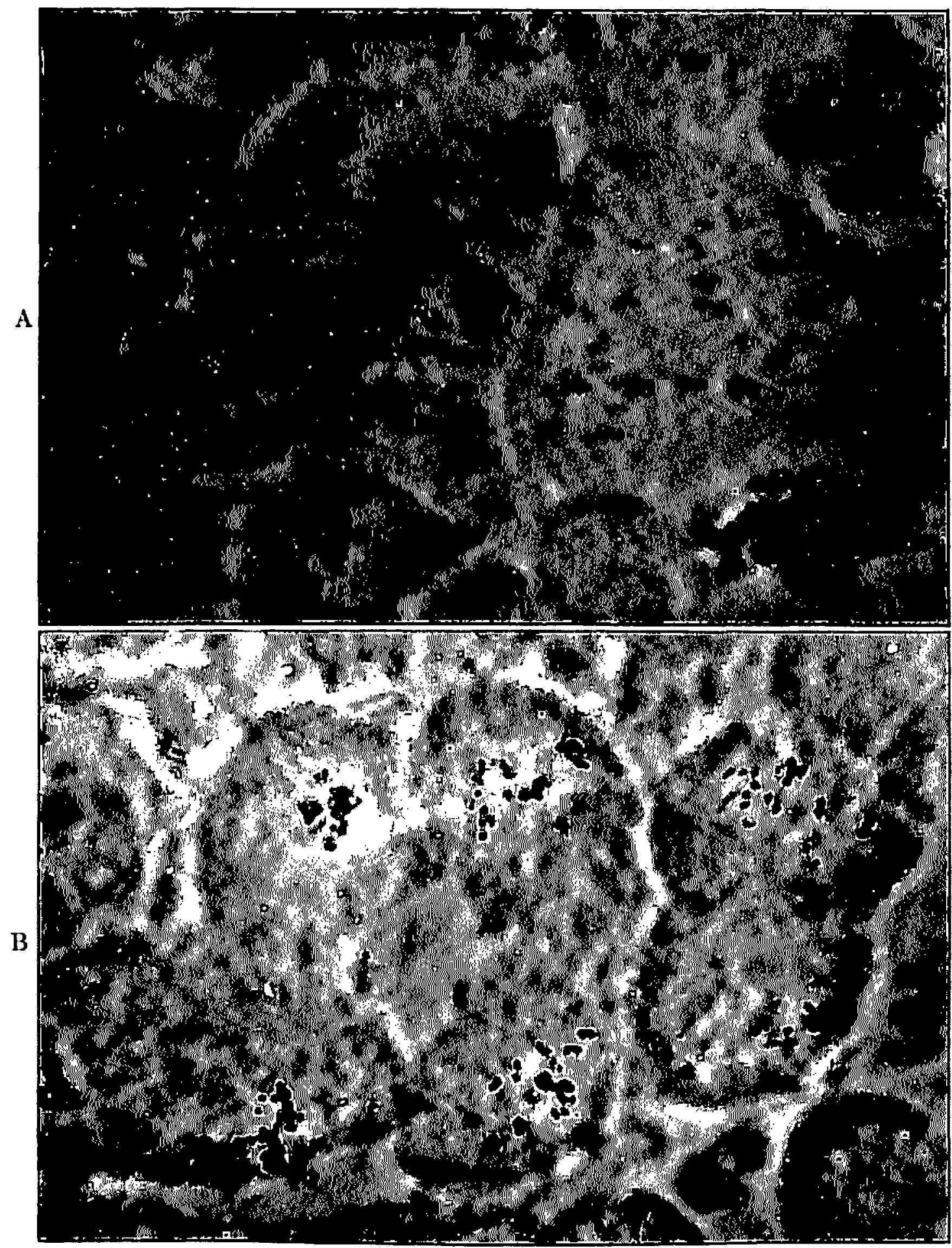

FIG. 8.-Nearly correct segregation in anaphase following asynaptic metaphase I: $A$, In the cell (a) the groups will probably be $17+17$. B, Various late anaphases showing a far-gone separation of chromatids. Magnification $1500 \times$. Squash preparations.

these chaotic pictures really represent a moment of a short, asynchronous pairing, or coorientation of homologues, is assumed from the abundance of late anaphases wherein a fairly good segregation near to $17+17$ has occurred (fig. 8). But (quite uneven numbers in the anaphase groups are also 
common, showing that this touch-and-go method of reduction is not very reliable.

Transversal sections of the sperm bundles show $256=2^{8}$ sperm heads in each bundle. Because the meiosis has doubled the cell number twice, there must have been six spermatogonial mitoses.

Sometimes polyploidy was observed among the germ cells. In one diplo-

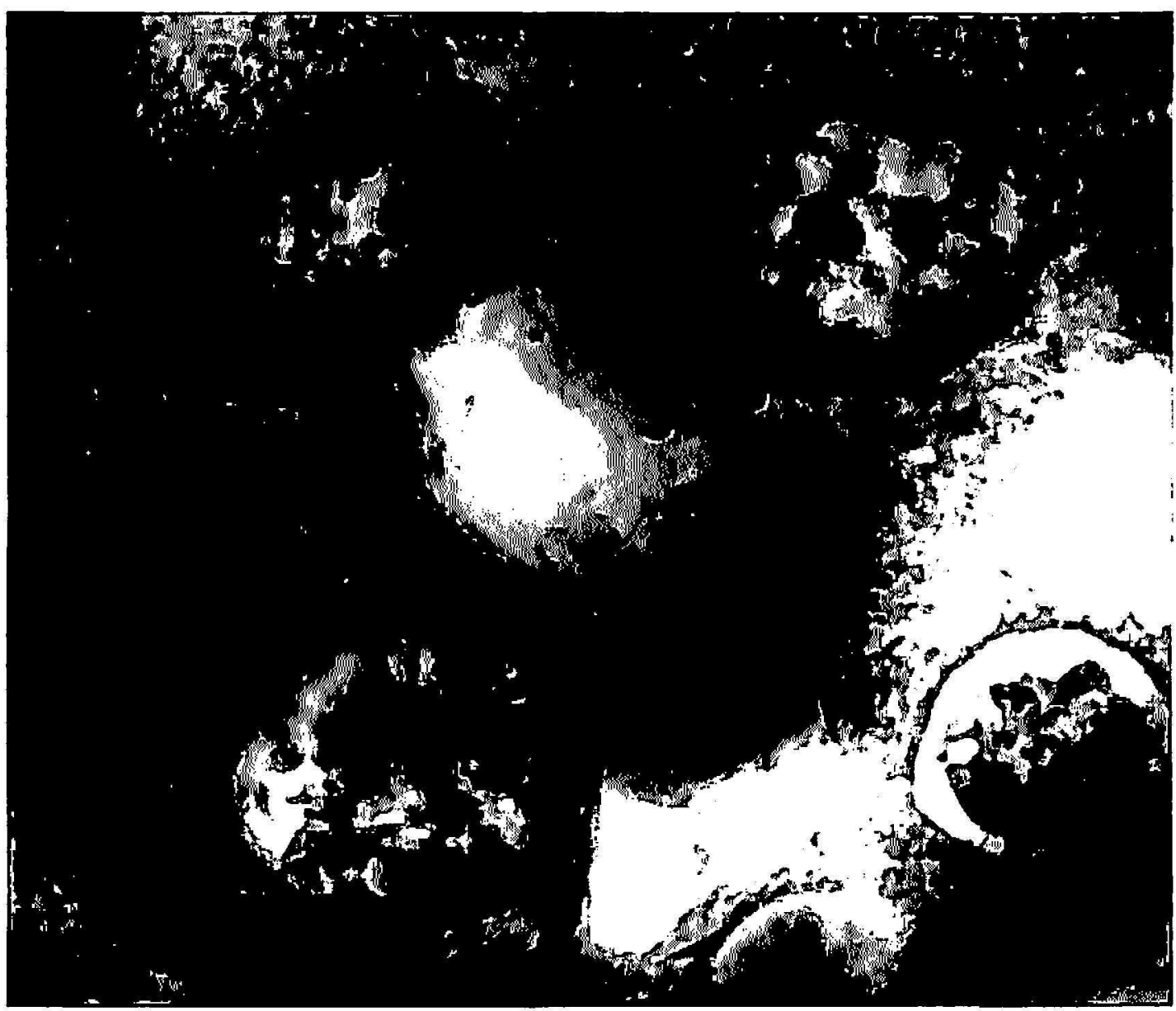

Fic. 9.-Variation of cell and nucleus size in a diplotenic spermatocyst of a larva 15 days old. Magnification $1500 \times$. Sectioned preparation.

tenic cyst the spermatocytes were of very variable size, apparently of different ploidy and aneuploidy degrees (fig. 9). (One bundle of spermatids in a late phase of spermiohistogenesis showed two large, apparently polyploid cells (fig. 10). These aberrations are caused by changes that occurred before the abnormal pupal spermatogenesis. Irregularities of this type are sporadically encountered in insect spermatogenesis, and can be considered normal as long as they are infrequent.

The main part of the follicle lumen becomes filled by spermiohistogenetic spermatids during this period. The reserve of spermatogonia is exhausted, or 
nearly so. At this stage the metamorphosis is completed and the adult emerges.

\section{Adults 1 to 2 Days Old}

The follicle contains mainly spermatozoon bundles and phases of spermiohistogenesis. No meiotic divisions were seen, but there were some cysts of prophasic spermatocytes. Some spermatogonia were also sometimes left in the apex. The membrane of the testis was thin, the contents partly drained,

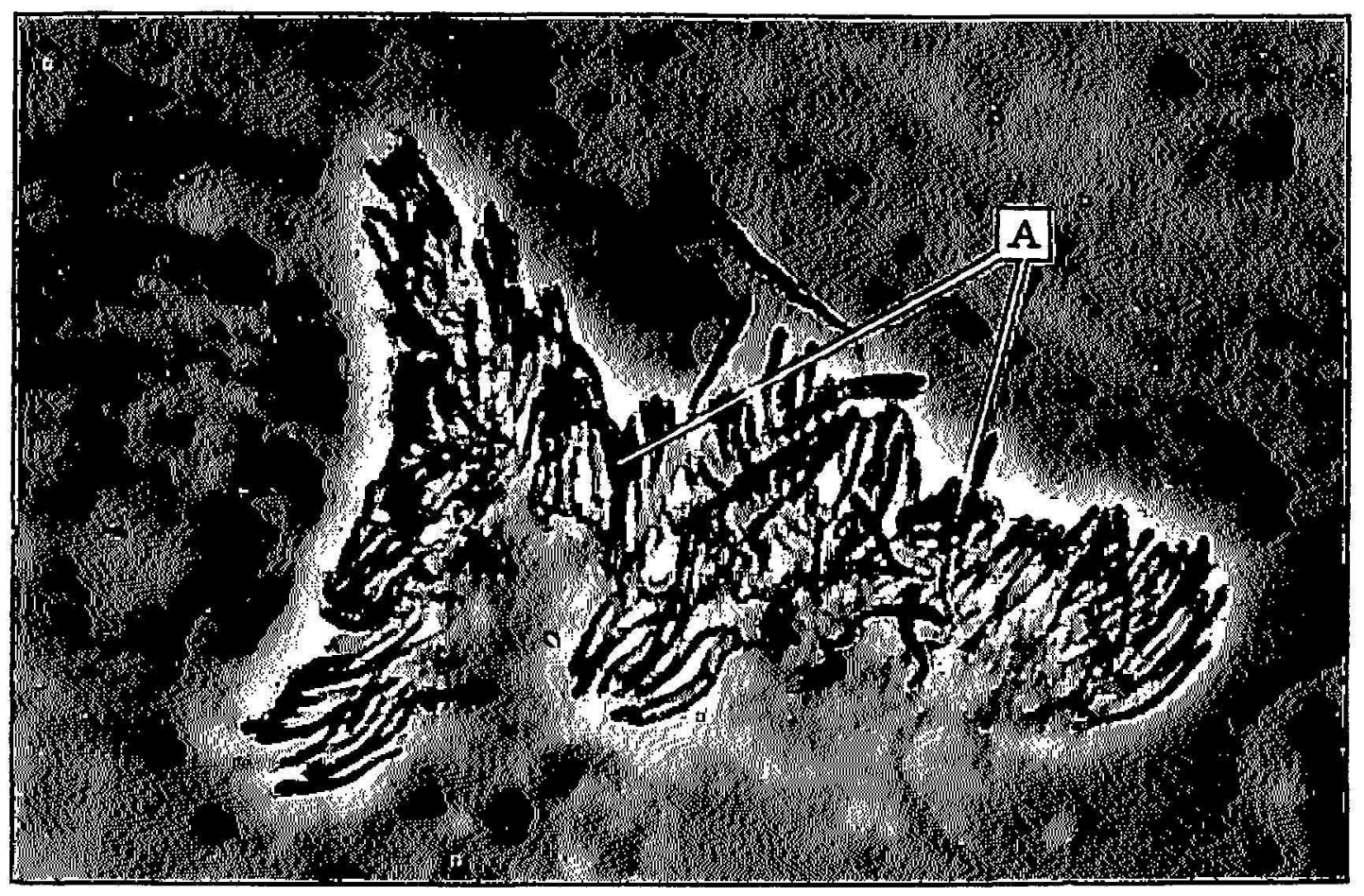

FIg. 10.-A, Two big, presumably polyploid sperm-heads in a bundle of late sper miohistogenetic cells. Magnification $1800 \times$. Squash preparation.

and the whole testis slightly collapsed. There were numerous spermatocysts in process of degeneration (fig. 11).

\section{OOGE.TESIS}

Development of the ovaria was not followed in detail. The production of eggs from oogonia is a long process lasting at least half of the entire life cycle. The oocytes are formed during the larval life. They grow first very slowly, and continue so during the main part of the pupal period. In the last 1 or 2 pupal days a rapid deposition of yolk begins in the most proximal oocytes (fig. 12). The process continues with tremendous rapidity in the adult female, the abdomen of which becomes filled with nearly ripe oocytes. The curious flat form of the eggs develops in the body of the female. The 


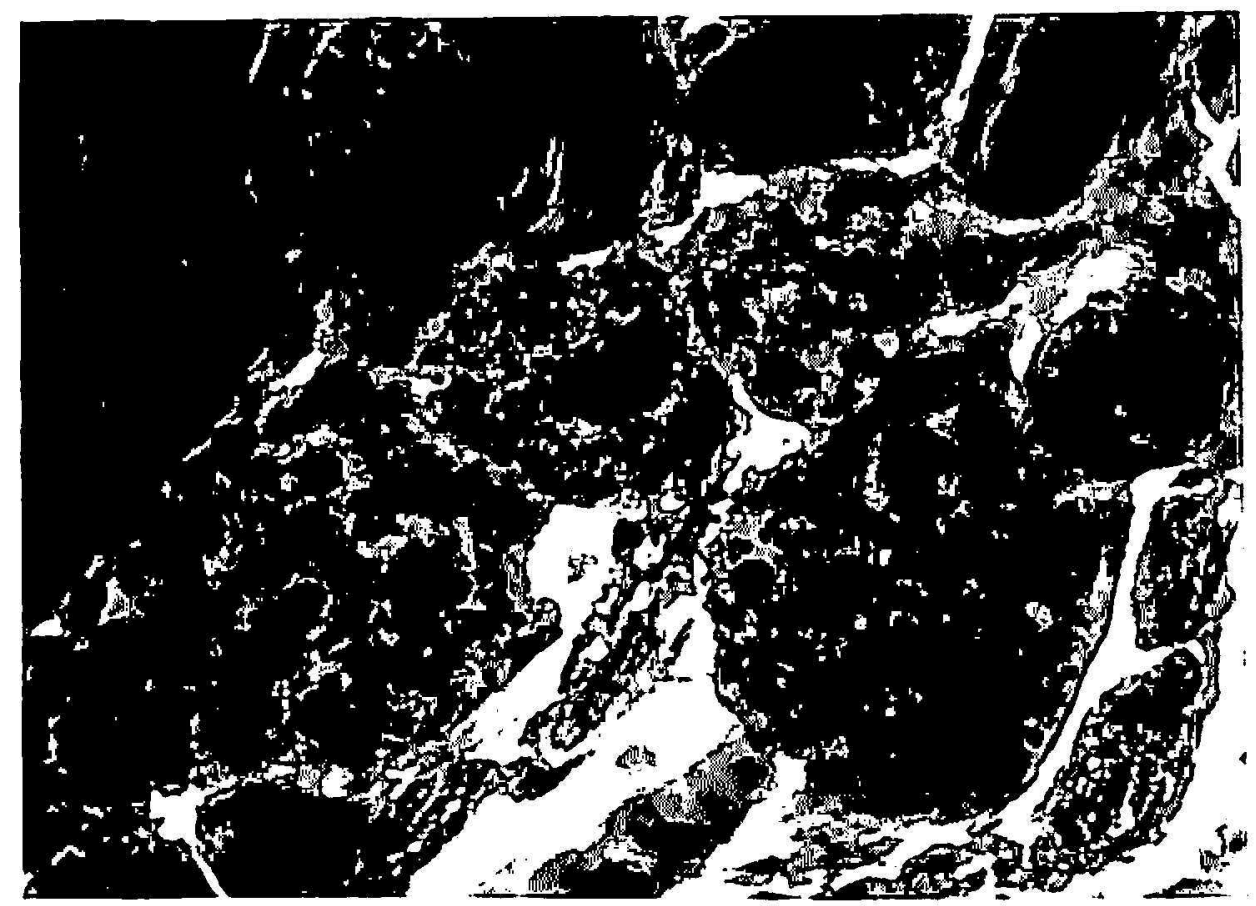

Fig. 11.-Degeneration of whole spermatocysts in testis follicle of an adult 1 day old. Magnification $1200 \times$. Sectioned preparation.

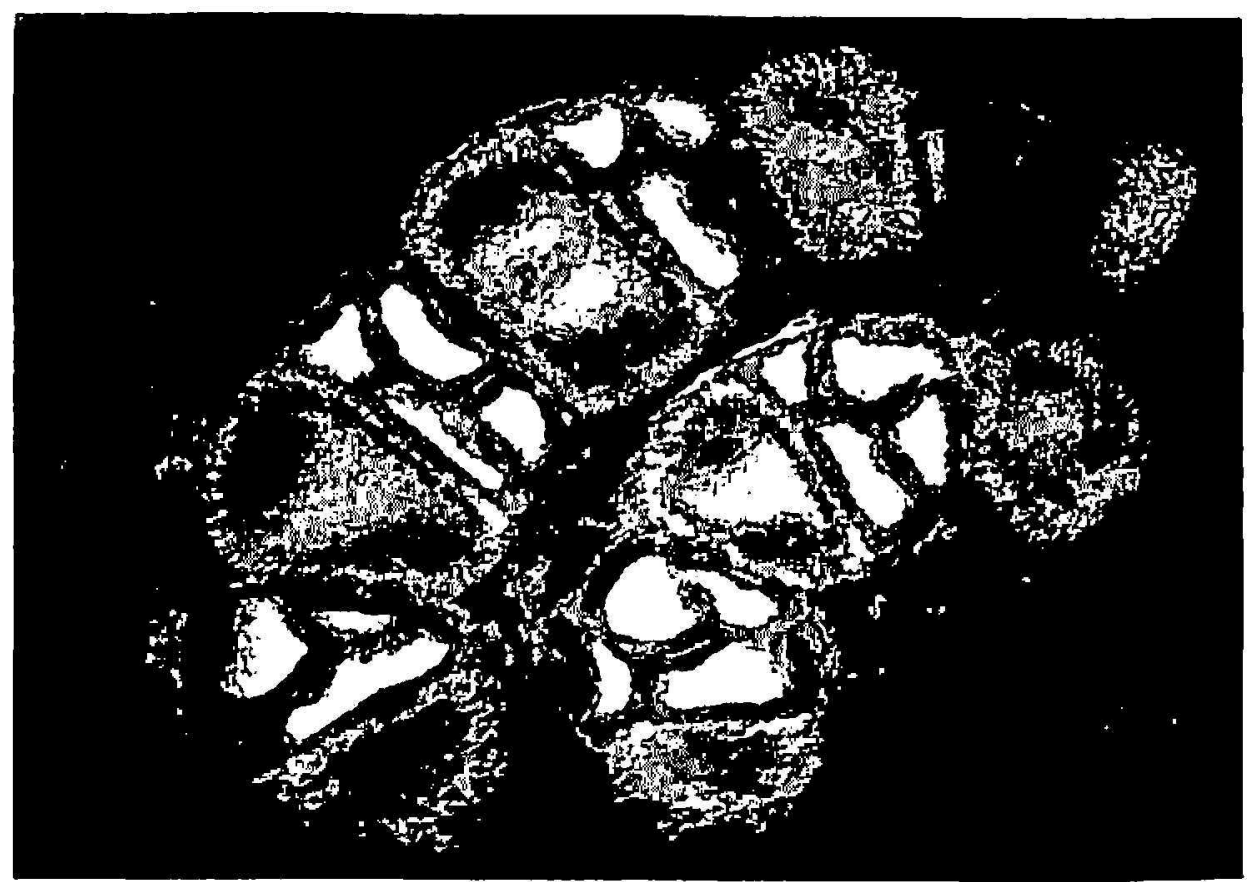

FIG. 12.-Beginning of the intense yolk deposition in oocytes of a pupa 6 days old. Each oocyte is accompanied by 4 nurse cells. In this phase the structure of cytoplasm of the oocytes and the nurse cells is quite different (7), as suggested also by this darkfield photograph. Magnification $125 \times$. Sectioned preparation. 
reduction divisions take place. No separate polar bodies are formed, owing to the strong chorion of the eggs. As the determination of chromosome numbers was not attempted in the female meiosis, sufficiently careful fixation and staining were not applied. The divisions encountered showed normal pairing.

\section{SUMMARY OF ABOVE OBSERVATIONS}

On the morning following oviposition the eggs contain an embryo of 16 to 64 cells. Distinct gonads containing spermato- or oogonies, can be found in the fourth day of larval life.

Rapid growth of the testes follows to the fifth larval day, owing to the multiplication of spermatogonia. Six successive generations of spermatogonia are formed. Meiosis starts in the basal end of the testis follicle, when the first young spermatocytes of primary order appear in the sixth day of larval life. From the fifteenth day on, the larvae contain all stages of spermatogenesis, from the gonia to the spermiohistogenesis. Meiosis is normal during this time; 17 bivalents form, and the anaphases result in a correct segregation.

During the pupal stage meiosis is asynaptic and anaphase irregularities are usual. The first bundles of spermatozoa appear.

The divisions are completed in the adult male, although spermatogonia and spermatocytes can be still encountered. The testes are filled with spermatids in spermiohistogenesis and with spermatozoon bundles.

The process of oogenesis is very slow after the multiplication of oogonia and formation of the oocytes during the early larval days. A rapid deposition of yolk starts at the end of pupal life and continues in the adult. The eggs flatten before they leave the body of the female. Meiotic metaphases can be encountered in the flattened ovarial eggs.

\section{DISCUSSION}

THL: CHIROMOSOMLS

\section{Number and Morphology}

$X=17$ is a very low and unusual chromosome number for a lepidopteran. The most common haploid number in the order is 31 , and in Trichoptera, a phylogenetically close but lower group, a number as high as 30 pairs is the commonest (99). Therefore, there is no reason for considering the $\mathrm{n}=17$ of Diatraea as a primitive number. The diffuse character of the lepidopteran centromeres gives some theoretical basis for explanation of the high numbers by means of fragmentation of the chromosomes during evolution. Similarly, the joining together of such chromosomes should result in viable chromosomes, owing to the lack of pointed dicentry. In Dialraca there is no path 
to follow the course of evolution because further chromosomes of the Crambidac are unknown. The few known numbers from the closely related family Pyralidae are typically lepidopteran, and do not offer more help.

That lepidoptcran chromosomes are capable of rapid evolution from high to low numbers, is shown by the studies of lederley $(30)$ and Lorkovic $(54,55)$ on the satyride genus Lirebia, where numbers from $\mathrm{n}=8$ to $n=40$ occur in closely related species and among others the same number as in Dialraca saccharalis, $\mathrm{n}=17$. For other similar cases in lepidopterans see Suomalainen (88). Lorković's suggestion that the polyploidy is involved is probably not apposite here, and has been criticized $(98,99)$.

Considerable evidence has been collected to support the view that the centromere of the lepidopteran chromosomes is diffuse (88). No definite decision on this can be given for Diatraea saccharalis, but the few observations favor a diffuse centromere. In the first metaphase of meiosis the chromosomal spindle fibres are broad. No constriction was seen in the chromosomes, not even in the asynaptic prophase, where the chromosomes are undercondensed and show their linear structure better. In the first anaphase of asynaptic spermatocytes the chromosomes seem to be split in two, because of a gap that separates the chromatids. In this stage it is quite common for the chromatids to be more or less separated from one another, but they run together at the centromere if it is localized. In Diatraea they lie parallel.

\section{Asynapsis}

Besides the somewhat controversial amitosis, there are only two basic principles of nuclear division: Mitosis, which assures the continuation of the chromosome complement; and meiosis, which reduces the chromosome number to half, separating homologous chromosomes from one another. In mitosis, the chromosomes are synthetically doubled and, in that condition go to the metaphasic spindle in which the halves divide and go to separate poles. Chromosome doubling is delayed in the meiosis, and the double chromosome structure, corresponding to the developing bipolarity of the cell, is arranged by pairing of homologues. The pairs, or bivalents, are brought to the spindle, and the chromosomes of the bivalent part, and migrate to opposite poles. This segregates complete homologous sets of chromosomes, and halves the rhromosome number.

Sometimes cells enter into meiosis with unpaired chromosomes. Such asynaptic cells have little chance to produce normal gametes because the univalent chromosomes are unable to orientate in the spindle, and uneven numbers of ('hromosomes are brought to the daughter cells. However, there are cases where asynaptic meiosis is the rule, resulting in a perfect segregation, and viability of gametes. Thus in the dipteran family Cecidomyiidae 
$(35,63,64)$ and in some coccids $(43)$ the maternal and paternal chromosome sets are different in condensation and recognizable from the meiotic prophase on. The homologous chromosomes never pair, but the paternal and maternal sets are neatly segregated in the first meiotic division. On the other hand, no cyclical difference between the maternal and paternal chromosome is reported in the coleopteran cases Allica $(84,86)$, Alagoasa (95), and Hyperaspis $(83,84)$, where the asynaptic sex chromosomes segregate more or less correctly. In these cases a much reduced pairing tendency, resulting in a short coorientation or pairing at the metaphase plate, seems to assure good segregation.

However, in the somatic reductions of plants, the separating chromosome groups form in the prophase as in cecidomyiids and coccids, but without difference in the condensation cycle (4/4). In sodium nucleate-treated Trillium it was observed that the separating groups were the maternal and paternal sets (108), and the same condition is caused by cold in Allium (./5).

These examples show that the classic pairing of homologues is not a unicpue method of controlling the reduction division of the chromosomes. There are some factors latent in the prophasic cell which are capable of taking care of a correct segregation in lack of pairing of homologues. In our subject, Diatraca saccharalis, such factors apparently operate in the asynaptic spermatocytes, because the anaphase grouping $17+17$ (or nearly so) occurs so often. Also experimentally, after destroying the mitotic spindle by radiation, a sort of "reductional" anaphase movement with more or less equal chromosome groups occurred (109). All this does not mean that an occasional asynaptic cell would have much chance of good reduction division. Presumably most such cells are doomed to perish. But it is evident that one or more chromosomes, or cells, or the entire meiosis, sometimes may be controlled by factors causing segregation without previous conjugation.

For a causal explanation of such events we would need more knowledge of the physiology of a dividing cell than is at present available. We know most about the behavior of the chromosomes themselves. A prerequisite of a persistent bivalent is usually a chiasma formed between the homologous chromosomes. Such factors as the time limit of pairing, the pairing block, and chiasma frequency obviously play important roles in the occurrence of asynapsis. Chromosomes that are precociously condensed presumably do not pair when the pairing requirement of meiosis occurs. At the very critical moment they may still pair, but cannot form chiasmata, especially if the pairing blocks are short and the chiasma frequency low. In the former case a true asynapsis, or nonconjugation, is the result; in the latter, pairing is followed by desynapsis, because the nonchiasmate homologues do not kecp together. But even chiasmate bivalents can disperse in the socalled premetaphase stretch $(8 \tilde{)})$. 
Perhaps the spindle mechanism is even more involved in the matter than the premetaphase stretch would suggest. Provided meiosis arises from mitosis through cyclic discrepancy between the chromosomal division readiness and the spindle formation, asynapsis, and multipolarity-both found in slight cases of apyreny (see next section) - could be expressions of an excessive, abortive discrepancy. Observations made on certain snails (73) support this view; there the chromosomes not only remain unpaired but they divide precociously in the prophase of the apyrenous spermatogenesis.

Sometimes asynapsis is determined genetically. Crossing the moths Pygaera pigra and $P$. curtula, Federley (29) obtained an $F_{1}$ generation with complete lack of meiotic pairing. The chromosomes behaved as in mitosis and diploid gametes were formed. Introduction of a new parental set by backcrossing resulted in pairing of the two equal sets, but the chromosomes of the third set remained univalent. This is the classic example of "strangeness" between chromosomes preventing chromosome pairing in many hybrids.

A single gene is responsible for the anomaly in a desynaptic maize (j). It acts through suppression of chiasma formation, and, consequently, biralents fall apart. A similar case has been reported in Dalura (6). As such chromosomal events as condensation and chiasma formation are sensitive to environmental influence the milicu must be considered also as a source of the factors of asynapsis.

We do not have many observations at the chromosomal level of the asynaptic meiosis of Diatraea saccharalis which would enable us to understand the failure of pairing. One observation can be made: the asynaptic chromosomes are undercondensed in the premetaphase and the metaphase of the first division. Their condensation may increase until the corresponding anaphase. A cyclic discrepancy consequently exists between chromosome condensation and cell polarity. The asynaptic chromosomes may be said to show a slight regression to the mitotic condition, whereas the extrachromosomal events, including cell growth and polarity, proceed in the meiotic manner. As the chromosomes are short and the bivalents are arranged presumably by one chiasma only, the pairing may be prevented even by lesser cyclic difference. The chromosomes of asynaptic male Dialraea are not prepared for an equational first division, however. Their behavior is thus between the mitotic and meiotic one.

Because the asynapsis of Diatraca saccharalis occurs in a certain developmental phase it cannot be attributed simply either to genes or the environmental factors. There must be intervening factors closely related to the control of ontogenesis. In following section this will be discussed in connection with apyreny, with which asynapsis coincides. 


\section{APYRENY}

In a conversation years ago, the late Prof. Ferderley mentioned to the author that the end of the male meiosis of Lepidoptera is usually abnormal, resulting in asynapsis and apyrene spermatozoa. Apyreny was first described in Prosobranchia (65), where a part of the spermatids develop to enormous, complex, anucleate formations which seem to have a function as carriers of the normal spermatozoa. The degree of apyreny varies, however, in the prosobranchs, the milder cases being only chromosomal disturbances, especially asynapsis and abortive segregation (see Ankel (3), Portmann (74), and Pollister and Pollister (78)).

Lepidopteran apyreny has been studied to some extent by Meves (65), Goldschmidt (37,38), Gatenby (34), Machida (58), and Knaben (49), and was mentioned by some others. Not all students of lepidopteran cytology report it, but preference for larval stages as material (Saitoh 79,80) sug.gests that the later stages have not been useful. However, some authors have reported normal chromosome relations in male pupae, but some reports, like $\mathrm{n}=112$ in Phigalia pedaria Fabr. (77), could be errors caused by asynapsis. That normal meiosis occurs among the asynaptic one in the male pupa, seems established. Thus in Bombyx mori 40 percent of the spermatids produced during the pupal life are eupyrene (50).

Lepidopteran apyreny never takes such extreme forms as in the Prosobranchia. Chromosomal disturbances, especially an abortive segregation caused by asynapsis and multipolarity, seem to be typical external marks of meiosis leading to apyreny in the lepidopters. The beginning of the abnormal events coincides, more or less, with pupation.

Besides the Lepidoptera, there is only one insect group wherein a similar anomaly occurs with some regularity: the pentatomids. However, the abnormal spermatogenesis of the pentatomids is not caused by the lapse of time, but by topography, and is limited to one lobe ("harlequin lobe") of the testis (82).

\section{On the Causal Relations of Apyreny}

Inevitably, the question arises whether apyreny, polyphyletically evolved and so widely spread in three different evertebrate groups, might have some adaptive value that caused it to survive in the process of evolution. It seems probable that some of the spermatids are sacrificed for the nutrition of others. Similar phagocytosis is quite common in the insect metamorphosis, and even in gametogenesis the nurse cells are utilized and sacrified for the growing oocytes. In normal spermatogenesis also the cytoplasm discharged from the spermatids during the spermiohistogenesis is supposedly utilized for such purposes (18). In extreme cases, such as Aphodius in the Coleoptera (93), the diplotenic growth of the spermatocytes is 
remarkable, resembling oogenesis, but the bulky cytoplasm is transferred to a cyst cell during the spermiohistogenesis, and the cyst cells are later "digested" in the vas deferens.

Neither of these sacrifice methods need necessarily be developed for nutritional purposes. Why must cytoplasm, even extra cytoplasm on occasion, be synthesized in the cells to be eliminated then in favor of other cells? Or why must a whole atypical meiosis occur before the cells are sacrified? The answer may be that complicated compounds like DNA are needed, and are produced only during such processes (53). But the initial course of the spermatogenesis is completed without such help. In Diatraea saccharalis the production of apyrene cells starts so late that no normal growing cells are present to be served. Would it be a disadvantage for the species if the spermatogenetic process were to continue normally, more slowly, but without sacrifying germ-line cells?

Trying to answer such questions leads easily to the opinion that these phenomena may be just a kind of curious "ballast" (82,93), tolerated by evolution, because not particularly disadvantageous. But there is another approach to the problem. The aberrations may be produced as byproducts by a force majeur, a factor controlling important processes of high adaptive value. Discharge of cytoplasm from the spermatids is a comprehensible need, if we remember that the sperm cell has only one function: i.e., to move towards the egg carrying the chromosome set. Minimum cytoplasm promotes the movement and permits a higher concentration of cells-both of which are useful. In Aphodius the factors determining yolk deposition are not completely ruled out from the male, and the process starts, although it is soon suppressed. A special system of absorption cells has developed to liberate the spermatids from the excess of cytoplasm. In neither of these cases need we suppose that the nutrition requirement existed primarily. Other more general factors are responsible for the processes. If the species has been able to develop a method of utilization of the removed cellular material, that is another matter. Similarly, abortion of entire spermatids could be caused by some general process. The abortive cells may then serve for nutrition, or even for some very special purposes.

Should we suspect the influence of any known major factor in the abortive spermatogenesis of the lepidopters and the pentatomids? Apparently, the answer is affirmative, at least as to Lepidoptera.

\section{Relation of Apyreny to the Hormonal Control of Metamorphosis}

Studies in insect ontogeny have revealed that the development proceeds under hormonal control. Larval organogenesis, and continuation of gametogenesis up to the adult, are controlled by the juvenile hormone secreted by the corpora allata $(36,104)$. In holometabolous insects the ju- 
venile hormone permits larval molting but not pupation. Before pupation can take place the juvenile hormone must disappear or diminish to near zero. Thus, the simplest explanation of the abortive trends of meiosis during the pupal stage would be that it is not effectively controlled by the juvenile hormone. The matter must be more complicated, however, because there are holometabolous insects, like Melolontha hippocastani (91), that have a normal spermatogenesis in the pupa. Anyway it seems significant that the change from normal to abnormal meiosis coincides with the time of radical hormonal changes. Another observation that may be significant is that in the Lepidoptera only, the hormonal control has been found different and more complicated than in other insects studied (9). The absence of the juvenile hormone has not affected the normal spermatogenesis in some lepidopters $(46,81,109,107)$, but the presence of the prothoracic hormone has been necessary for maintaining it (106). The studies of Cleveland and his coworkers (22,23) on the effects of this hormone (ecdysone) in Protozoa show that both gametogenesis and meiosis are controlled by it, and it may be responsible for endomitotic polyploidisation also.

The only one who has made experiments on the determination of the lepidoteran apyreny is Machida (58) who transplanted testes from pupae to larvae, and vice versa. The results showed that the factor causing apyreny is in the pupal hemolymph. The membrane of the spermatocyst may be able to prevent the influence of the factor to some extent.

These indices are sufficient to reserve for future studies the working hypothesis that hormonal changes are responsible for the initiation of the asynaptic meiosis in the male pupa of lepidopters. Certain chromosomal properties (see Asynapsis) may cause further sensitivity in that insect group.

In regard to oogenesis the present observations on the rapid growth of oocytes in the adult Diatraea saccharalis are in accordance with the observations of Engelmann (28), Ichikawa and Nishiitsutsuji-Uwo (46), and Williams (107), who encountered the corpora allata very active in adults and stimulating the deposition of yolk.

The anatomically localized case in the pentatomids cannot be explained too simply. We must assume the presence of some local factor in the cells themselves, or in the harlequin lobe. At least there is one local agent capable of controlling the initiation of meiosis: the glandular apical cell, or Verson's cell, in the distal end of each follicle of the insect testis. Malfunction, or lack of function, of such a local controller could be a reason for abnormal behavior of a restricted area.

We do not know the hormone relationships of Prosobranchia, but the gonad is hermaphrodite and turns to oogenesis after a period of spermato- 
genesis. Therefore the possibility exists that hormonal changes play some role in the apyreny of the prosobranchs also.

\section{RADIATION OF THE GAMETOGENESIS}

\section{Theoretical Expectancy of Sensitivity}

Sterilizing effects of the radiation of the gametogenesis fall into at least five categories: 1 , Gene mutations; 2 , chromosome mutations; 3 , disturbance of segregation; 4, extranuclear disturbances; and 5, cell death.

The first two categories were widely discussed in many connections recently, and do not need to be touched on here. The first category remains beyond the cytomorphological approach. Maybe the meiotic stages younger than diplotene, the preceding interphase, as well as interphases of all premeiotic mitoses, should be expected to be extrasensitive to gene and chromosome disturbance, because the synthesis of DNA (the genes) usually occurs in the late interphase $(62,75)$. Data supporting such expectancy are available, although the division stages seem sometimes to be most sensitive (27).

The supposedly diffuse centromere puts Diatraea and other lepidopters in a special position insofar as chromosome mutations are concerned. The fragmentation of chromosomes per se should not cause difficulties, because the fragments are capable of correct mitotic behavior. Meiotic irregularities may occur, however, so long as the fragment heterozygosity persists, and even later, if chiasma frequency or other pairing prerequisitions limit the tolerance of fragmentation.

An abortive segregation itself can cause sterile gametes. Chromosomal causes for it are well-known, such as asynapsis, desynapsis, multivalents, laggards, stickiness, nondisjunction, and certain chromosome mutations. As compared with the chromosomal aberrations caused by irradiation, we are less informed on the response of the spindle mechanism itself to the rays. Naturally occurring spindle anomalies like mono- and polycentric mitoses, and endomitosis, suggest that artificial disturbance should be possible. It is well known that chemicals like colchicine really suppress spindle formation, or somehow affect $(62,89)$ the spindle function. Some spindle disturbances by radiation, varying from unusual shape to failure of normal division and to endomitosis, have been reported $(20,68,76,78)$. Finally, the ultraviolet microbeam experiments of Zirkle and coworkers (109) nicely demonstrated the radiosensitiveness of the spindle, and the resulting errors in segregation.

Hypothetical, but highly interesting, is the possibility of disturbing the development of meiosis from mitosis by irradiation. Provided meiosis results from a discrepancy in the synthesis and cyclic behavior of the spindle 
and the chromosomes, as suggested by Darlington (26), Cleveland (21), Oksala (70,71), and Virkki (92), disturbing the process would probably cause anomalies leading to abnormal segregation. In insects a series of observations $(69,92)$ suggests that the meiotic situation develops gradually in spermatogonia (see also Monesi (66) for gradual changes of DNA synthesis during the premeiotic divisions). Conceivably the cell generations should be treated just prior to the meiosis.

In addition to the centrosomes, the cytoplasm contains other inclusions of vital importance. Mathur (61) has shown that such inclusions can be disturbed in their development by the radiation of the spermatogenesis. The resulting spermatozoa are probably largely functionless.

It has been long known that radiation causes death of the spermatogonia in mammals, an effect which was used for temporary sterilization even of humans before the radiation hazards were well understood.

Finally, attention must be drawn to the fact that the radiations are usually whole-body treatments. This is true particularly of treatments for practical needs, when the material must be handled in masses. Damage caused in somatic organs may influence gametogenesis. For instance, changes in the hormonal control of gametogenesis could cause sterility. Failure of pupation in the moth Ephestia kuehniella after radiation could be caused by such a hormonal disturbance (102).

Thus it seems, at least theoretically, that there are vulnerable phases distributed during the whole course of gametogenesis, and even outside the germ line. From the practical point of view it would be useful to know the most radiosensitive stage of the gametogenesis, and the typical cytological and genetic changes caused by the radiation in it. The cytological check-up would then help in selecting the most successful age and the stage for the treatment.

\section{Previous Data on the Radiosensitivity of Gametogenesis}

Table 1 contains a restricted but representative collection of data on the radiosensitivity and effects of radiation in different stages of spermatogenesis.

Most work has been done with Drosophila. It is supposed that in matings 2 to 5 days after radiation, sperm was used which, at the time of radiation, was either mature or maturing (spermiohistogenesis); in matings 6 to 7 days after radiation, sperm that was in spermatocyte; and in matings 8 to 13 days after radiation, sperm that was in spermatogonium stages at the time of radiation. Because Drosophilas are very suitable objects and genetically so well studied, it has been possible to detect the nature of the effects by planned matings. Almost all authors agree that the postmeiotic stages, especially the spermatids, are very sensitive. Effects of the treat- 


\begin{tabular}{|c|c|c|c|c|c|c|c|}
\hline Organism & $\begin{array}{l}\text { Sper- } \\
\text { mato- } \\
\text { Bonia }\end{array}$ & $\begin{array}{c}\text { Growth } \\
\text { period } \\
\text { of cyte } \\
\text { I }\end{array}$ & $\begin{array}{l}\text { Late } \\
\text { pro- } \\
\text { phase, } \\
\text { meta- } \\
\text { phases }\end{array}$ & $\begin{array}{c}\text { Sperma- } \\
\text { tids }\end{array}$ & $\begin{array}{c}\text { Sperma- } \\
\text { tozoa }\end{array}$ & Observations & Author \\
\hline Oryclolagus cuniculus & + & & & & & Necrosis & Heller (41) \\
\hline Mus musculus & + & & & & & $\begin{array}{l}\text { Gonia: Prolongation of interphase and prophase, } \\
\text { stoppage of proliferation, probably disturbed } \\
\text { DNA synthesis, necrosis. }\end{array}$ & Bryan et al. $(16,17)$ \\
\hline Do. & + & & & & & $\begin{array}{l}\text { Gonia: Loss of nuclear detail, necrosis. Sperinato- } \\
\text { cytes may suffer. }\end{array}$ & Oakberg (67) \\
\hline IIacaca mulatta & + & + & & & & $\begin{array}{l}\text { Gonia: After } 400 \mathrm{r}, 11 \text { days later, chromosomal dis- } \\
\text { turbances in } 68 \text { percent, } 2 \text { years later, in } 11 \text { per- } \\
\text { cent of gonia. Inversions arise in growth period. }\end{array}$ & $\begin{array}{l}\text { Dubinin (27) } \\
\text { Tinyakov } c l \text { al. }(90)\end{array}$ \\
\hline $\begin{array}{l}\text { Drosophila melano- } \\
\text { gaster }\end{array}$ & + & & & & & Multipolarity, clumping and lagging of chromosomes. & Bloom (8) \\
\hline Do. & & & & + & + & $\begin{array}{l}\text { Spermatids more sensitive. Dominant lethals, point } \\
\text { mutations, gynandromorphs, hyperploids. }\end{array}$ & Lüning $(56,5 \gamma)$ \\
\hline Do. & & & & & + & $\begin{array}{l}\mathrm{X} \text { chromosomes more sensitive in receptaculum of } \\
\text { the female than in the male. Recessive lethals. }\end{array}$ & Bonnier et al. (10) \\
\hline Do. & + & & & + & & $\begin{array}{l}\text { Gonia: Damage probably causes reduction in sperm } \\
\text { number. Spermatids: Sex-linked lethals. }\end{array}$ & Auerbach (4) \\
\hline
\end{tabular}




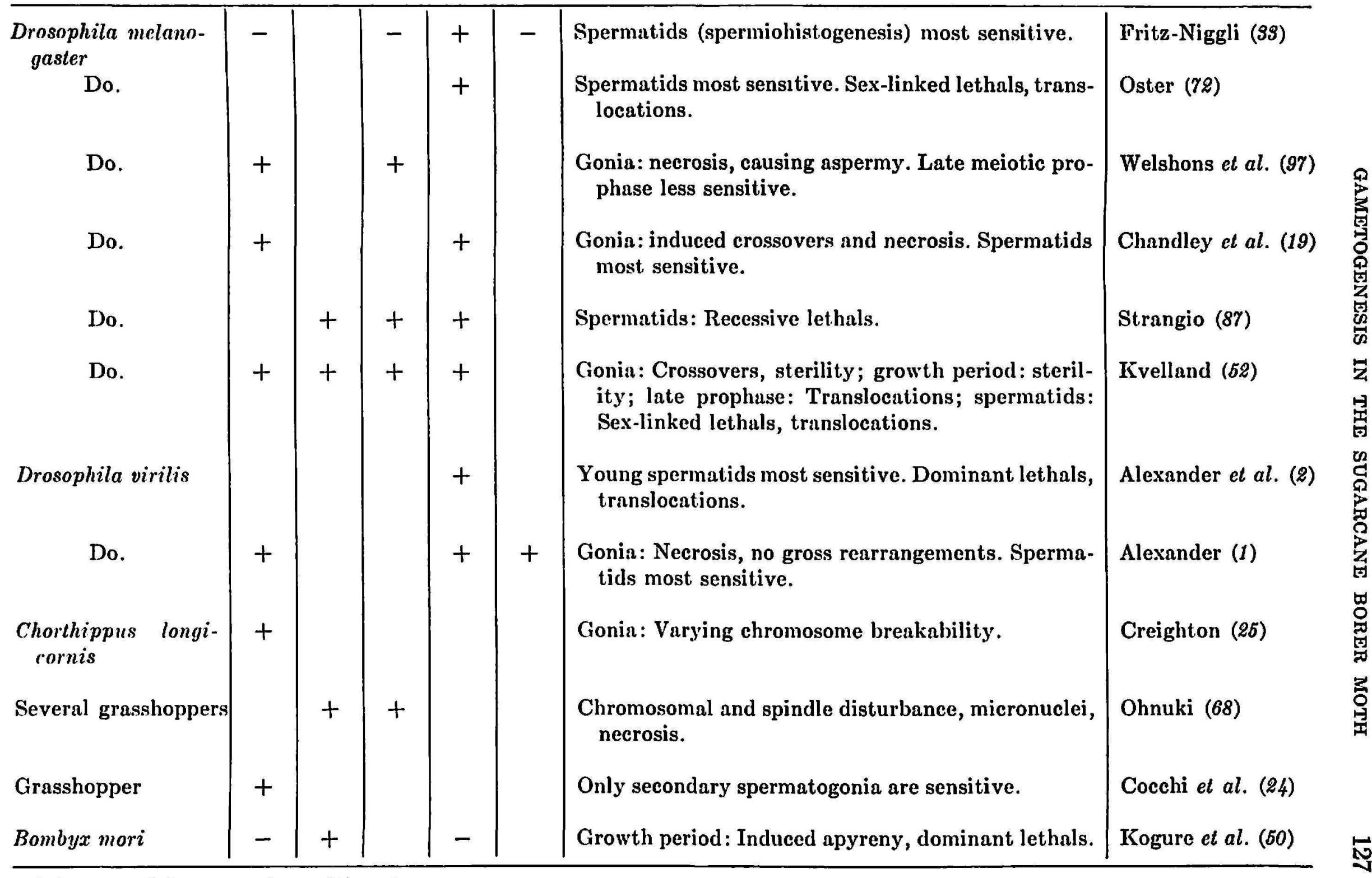

${ }^{1}+=$ sensitive; $-=$ insensitive stage. 
ment of spermatids are translocations, dominant lethals, and sex-linked lethals. One author, Bloom (cf. table 1), reported severe effects in spermatogonia, but another, Fritz-Niggli, stated that spermatogonia are insensitive. Several authors expected cell death after treatment of spermatogonia. Kvelland pointed out that treatment of gonia, and of growing spermatocytes, might cause a sterility which remained undetected in genetic experiments. Chandley and Bateman also held it possible that affected spermatogonia might die because chromosome mutations are never collected from late matings. Probably the vast majority of the male gametes can be abortive, the remaining normals still giving, genetically, an impression of fertility, as in a variety of maize reported by Beadle (5). Welshons and Russell finally showed that there is extensive death of spermatogonia in Drosophila after radiation, resulting in a period of aspermy. Thus it seems that the higher sensitivity of the meiotic, and, especially, of the postmeiotic stages emphasized by many Drosophila workers, is largely a result of the technique used.

Contrary to the Drosophilas, the mammals are inconvenient objects for such detailed analyses. Here the checking technique has been mainly cytological. The spermatogonia are considered the most sensitive stages. Their vulnerability seems to be much higher than that of the insects because low doses only are needed to produce remarkable effects. The interphases and prophases are prolonged, the proliferation of gonial cells stops, and necrosis occurs. An aspermic period is the result.

The data from insects other than Drosophila are restricted and somewhat contradictory. In grasshoppers secondary spermatogonia are said to be sensitive, and chromosome mutations have been seen to occur. As their later fate was not followed, nor were their genetical effects checked, it is hard to say whether the sensitivity was less or greater than in Drosophila. In the sickworm Kogure and Nakajima found the spermatids very resistant to dominant lethals, which is surprising when compared with the data on Drosophila. Also the spermatogonia were very resistant in Bombyx. The authors do not state whether necrosis of spermatogonia occurs, but they treated stages where gonia were already in minority among the testis contents.

This work is of special interest for us because the silkworm is one of the few moths treated by irradiation, and the only one checked cytologically at the same time. As in Diatraea saccharalis, also in Bombyx mori there occurs an apyrenous spermatogenesis during the pupal stage, although about 40 percent of the cells remain eupyrene in Bombyx.

The most interesting observation of Kogura and Nakajima (table 1) was that apyreny can be induced by radiation. Thus treatment of larvae at the beginning of the fifth instar with $3,000 \mathrm{r}$ reduced the eupyreny to 7 to 
14 percent of spermatocysts. Because the apyrene spermatozoa are functionless a remarkable reduction of fertility occurs, even if mutations introduced at the same time are not taken in account. From the cytological picture of the testis contents at the time of treatment the authors calculated that the sensitive periods for inducing apyreny are the early prophase stages of the spermatocyte $I$. Treatment of normally arisen spermatids did not change the course of the spermatogenesis towards apyreny. Dominant lethals affecting the egg hatchability were observed also. They are supposed to arise in spermatocytes beyond diakinesis, where anomalous chromosome relations were also seen immediately after the treatment. Apparently the data of Kogura and Nakajima are very valuable in planning induced male sterility in other lepidopteran species.

Much less radiosensitivity was observed by the same authors in the female silkworm. The experiments made by Whiting $(100,101)$ with the wasp Habrobracon, however, showed phases of different radiosensitivity during the oogenesis. Oogonia are injured badly by $2,500 \mathrm{r}$; treatment of the early prophase results in larval death and treatment of diakinesis in death after hatching; treatment of metaphases results in quicker death. The ovarium may suffer atrophy and the total number of eggs be reduced (39).

\section{Practical Conclusions on Treatment of Diatraea saccharalis}

We know now, owing to the cytological check-up of the gametogenesis of Diatraea saccharalis, where the different phases can be encountered. It may be a risk to treat the early embryonal stages, because it would result in damage widely distributed in the forming body, and thus lower the viability. Anyway, we know that in the first 12 hours of embryonal life we would encounter synchronous cleavage mitoses, and immediately after that, blastoderm formation. The most interesting part of the history begins, however, when the secondary gonia appear. The results provide the following guide for planning the radiation of spermatogenesis:

Cell lype to be radiated

Cleavage cells

Primordial spermatogonia

Spermatogonia and meiotic prophase

All stages of meiosis and spermiohisto-

genesis

Asynaptic meiosis and spermiohistogenesis

Spermiohistogenesis and spermatozoa in

bundles
Slage and age when most abundantly available

Up to the morning following oviposition

Larvae 2 to 4 days old

Larvae 7 to 10 days old

Larvae 15 to 33 days old

Pupae

Adults

Unfortunately the mating habits of the female Diatraea saccharalis are too little known to reach a decision whether aspermy and apyreny are 
sufficient to suppress the population, or whether emphasis should be directed to producing lethal mutations. If the female copulates only once, aspermy and apyreny would be fully sufficient. In that case every copulation with a sterile male would cause failure of progeny. But if the moth is polygamous and is copulating with many males, the mere sterility of the treated males would not suffice, because the chance is great that the moth copulates later with fertile males. In that event the treated males should carry lethal mutations in functioning spermatozoa. In this way radiation damage would become effective in the progeny, independently of the mating mode of the female $(11,12)$.

IN CASE OF MONOGAMY.-Treatment of secondary spermatogonia and early spermatocyte stages promises results in the form of apyreny and aspermy. For this larvae 7 to 10 days old should be treated. Lethal mutations are not less efficient, however.

IN CASE OF POLYGAMY.-Introduction of lethals should be attempted, treating the stage where they seem to occur best in Drosophila, the spermatids. If they appear to be insensitive, as reported in Bombyx, (table 1) late prophase and metaphase of the spermatocyte I should be tried. As the meiosis in the male pupa is highly, probably completely abortive, it would be waste of time to treat it for inducing mutations in spermatocytes. But the pupal situation is advantageous if we have to treat spermiohistogenesis. The spermatids encountered in the pupa are yield of the normal meiosis of the larval stage. This means that a large part of the spermatids produced by the normal meiosis can be treated here at the same time and without fear of meiosis continuing later.

TREATING ALL STAGeS simultaneOUSLY.-How the spermatogenesis proceeds offers one more facility. Because it starts in the basal end of the follicle and proceeds continuously towards the apex, there are no essential changes in the frequency of the different phases during the last two larval weeks. The number of spermatogonia decreases, of course, and the number of spermatids increases, but both are present.

Thus, at present, the following condensation from the tabulation on $p$. 129 gives the most suggestive instructions:

1. To affect spermatogonia and early spermatocytes, treat larvae 7 to 10 days old;

2. To affect all stages of spermatogenesis, treat larvae more than 15 days old;

3. To affect spermiohistogenesis, treat pupae.

Tracking the oogenesis does not produce such a variable series of observations as found in spermatogenesis. Oogonia can be encountered in the same ages as spermatogonia. Early meiotic prophase continues during most of the life cycle. If the yolk deposition should be disturbed, we know 
that it starts in old pupae. Treating mature eggs presumably results in their sterility, but Diatraea does not have many mature eggs in its ovaries at one time.

The above guide is based on material reared in the warm, tropical lowlands in Río Piedras. In the geographical area of distribution of Diatraea saccharalis there are regions where winter or excessive drought occur. Both conditions cause larval diapause $(14,47)$. Prolongation of all stages is caused already by milder lowering of temperature (13). Where such environmental conditions affect the development, the above data must be modified or rechecked.

If a longer drought diapause occurs, or a hibernation, the same thing will probably occur as in Arctic and Subarctic arthropods when they accommodate themselves to the winter; the spermatocytes beyond the pachytene disappear gradually, and some accumulation of the pachytene occurs. If the exposure to cold is sudden the occurrence of phases may remain unaltered for months (94). Such observations may serve as hints for the testis treatment. If we prefer to eliminate stages later than the pachytene, and radiate the early meiosis, we could probably do so with help of cold treatment. Recent studies by various authors $(42,105)$ show that the diapause is principally controlled by the photoperiodism. Thus there are simple methods, suitable for mass handling in laboratories, and apparently capable of partial control of the testis contents.

\section{SUMMARY}

Diatraea saccharalis (F.), the only cytologically checked crambid moth up to the present, has an unusually low chromosome number for a lepidopteran, $n=17$. The chromosomes apparently have a diffuse centromere.

The premeiotic development of the gonads becomes more distinct after the fifth larval day, when the secondary gonia appear. The oogenesis proceeds very slowly after the formation of oocytes. A rapid deposition of yolk starts at the end of the pupal stage, and continues in the adult. The eggs flatten before they leave the body of the female. Meiotic metaphases can be encountered in the flat ovarial eggs.

Six successive generations of spermatogonia are formed. Meiosis starts in the basal end of the testis follicles, opposite Verson's cell. From the fifth day on the larvae contain all stages of spermatogenesis, from the gonia to the spermiohistogenesis. A normal meiosis occurs during this period.

The meiosis is abortive in the male pupa, because of asynapsis and anaphase irregularities. Bundles of spermatozoa appear as result of the spermiohistogenesis.

The divisions are completed in the adult male. The testes are partly 
drained, but contain spermatids in spermiohistogenesis, and spermatozoon bundles.

Based on these findings, and on former data on radiating the insect testis, the following condensed guide is suggested for the male sterilization of

\section{Diatraea saccharalis:}

1. To affect spermatogonia and early spermatocytes, radiate larvae 7 to 10 days old;

2. To affect all stages of spermatogenesis, radiate larvae over $\mathbf{1 5}$ days old;

3. To affect spermiohistogenesis, radiate pupae.

\section{RESUMEN}

Diatraea saccharalis (F.), la única especie de la familia Crambidae hasta ahora estudiada desde el punto de vista de la citología tiene un número de cromosomas excepcionalmente bajo para un lepidóptero: $n=17$. Los cromosomas aparentemente tienen el centrómero difuso.

El desarrollo premeiótico de los gónados es más preciso después del quinto día larval, cuando aparecen las gonias secundarias. Después de la formación de los oocitos la oogénesis tiene lugar muy lentamente. La yema comienza a formarse durante el último día de la crisálida y continúa en el adulto. Los huevos se achatan antes de salir del cuerpo de la hembra. Las metafases meióticas tienen lugar en los huevos ováricos achatados.

Se forman seis generaciones sucesivas de espermatogonias. La meiosis comienza en el extremo próximo de los folículos testiculares, al lado opuesto de la célula de Verson. Después de quince días las larvas poseen todas las etapas de la espermatogénesis, desde las gonias hasta la espermiohistogénesis. Durante este período, la meiosis es normal.

En la crisálida del macho la meiosis es abortiva a causa de la asinapsis e irregularidades anafásicas. Haces de espermatozoos aparecen como resultado de la espermiohistogénesis.

En el adulto macho ya no hay más divisiones. Los testes se vacían parcialmente, pero contienen espermátidos en la espermiohistogénesis y haces de espermatozoos.

A base de estos datos y otros datos anteriores sobre la radiación de los testes de los insectos, sugerimos las siguientes normas abreviadas para la esterilización del macho de Diatraea saccharalis:

1. Para alcanzar las espermatogonias y espermatocitos jovenes, trátense las larvas de 7 a 10 días de edad.

2. Para alcanzar todas las etapas de la espermatogénesis, trátense las larvas de más de 15 días de edad.

3. Para alcanzar la espermiohistogénesis, trátense las crisálidas. 


\section{LITERATURE CITED}

1. Alexander, M. L., Biological damage in developing germ cells of Drosophila virilis in oxygen and nitrogen with $14-\mathrm{MeV}$ neutrons, Proc. Nall. Acad. Sci. U.S. 44 1217-28, 1958.

2. Alexander, M. L., and Stone, W. S., Radiation damage in the developing germ cells of Drosophilia virilis, Proc. Nall. Acad. Sci. U.S. 41 1046-57, 1955.

3. Ankel, W. E., Die atypische Spermatogenese von Janthina (Prosobranchia, Ptenoglossa), Z. Zellf. mikr. Anat. 11 490-608, 1930.

4. Auebach, C., Sensitivity of the Drosphila testis to the mutagenic action of $\mathbf{X}$ rays, Z. indukt. Abst.-Vererbungsl. 86 113-25, 1954.

5. Beadle, B. W., Further studies in asynaptic maize, Cytologia $4269-87,1933$.

6. Bergner, A. D., Cardledge, J. L., and Blakeslee, A. F., Chromosome behavior due to a gene which prevents metaphase pairing in Datura, Cytologia. 6 19-37, 1934.

7. Bier, K., Unterschiedliche Reproduktionsraten im Eu- und Heterochromatin: ein Weg zur Kerndifferenzierung? Verh. Deutsch. Zool. Ges. Saarbrücken 1961, pp. 102 10, 1961.

8. Bloom, W., The Cell, pp. 550-97 in : Histopathology of Irradiation from External and Internal Sources, edit. W. Bloom, McGraw-Hill, New York, N.Y., US, 1948.

9. Bodenstein, D., The Role of Hormones in Molting and Metamorphosis, pp. 878931 in: K. D. Roeder, Insect Physiology, John Wiley \& Sons, New York, N.Y., US, 1100 pp., 1953.

10. Bonnier, G., and Lüning, K. G., Sex-linked lethals in Drosophila melanogaster from different modes of X-ray irradiations, Hereditas 39 193-200, 1953.

11. v. Borstel, R. C., Population control by release of irradiated males, Sci.131 $878-$ $82,1960$.

12. v. Borstel, R. C., and Buzzati-Traverso, A. A., On the Role of Lethal Mutants in the Control of Populations, pp. 273-8 in: Radioisotopes and Radiation in Entomology, Internat. Atomic Energy Agency, Vienna, Austria, 304 pp., 1962.

13. Box,'H. E., Informe Preliminar sobre los Taladradores de la Caña de Azúcar (Diatraea spp.) en Venezuela, Dept. Ent., Ministro de Agr. Cría, Bol. Tecn. pp. 1-117, 1947.

14. - Investigaciones sobre los Taladradores de la Caña de Azúcar (Dialraea spp.) en Venezuela, Inf. Progr. 1947-49, Ministro de Agr. Cría, Bol. Tecn. 2 pp. 1-60, 1949.

15. Brelind, O. P., Studies on the chromosomes of mosquitoes, Ann. Ent. Soc. Amer. 64 360-75, 1961.

16. Bryan, J. H. D., and Gowen, J. W., A histological and cytophotometric study of the effects of x-rays on the mouse testis, Biol. Bul. $110229-42,1956$.

17.,-- , The effects of $2560 \mathrm{r}$ of $\mathrm{x}$-rays on spermatogenesis in the mouse, Biol. Bul. 114 271-83, 1958.

18. Buchner, P., Praktikum der Zellenlehre I, 336 pp., Berlin, Germany, 1915.

19. Chandley, A. C., and Bateman, A. J., Mutagenic sensitivity of sperm, spermatids, spermatocytes and spermatogonia in Drosophila melanogaster, $\mathrm{He}$ red. 16 363-75, 1960.

20. Clark, F., Cytogenetic studies of divergent meiotic spindle formation in $Z$ ea mays, Amer. J. Bot. 27 547-59, 1940.

21. Cleveland, L. R., The origin and evolution of meiosis, Sci. 105 287-9, 1947.

22. - - Sex induced with ecdysone, Proc. Natl. Acad. Sci. US 46 747-53, 1959. 
23. Cleveland, L. R., Burke, Jr., A. W., and Karlson, P., Ecdysone induced modifications in the sexual cycles of the protozoa of Cryptocercus, J. Protozool. 7 229-39, 1960.

24. Cocchi, U., and Ugger, B., Die Wirkung von Röntgenstrahlen auf den Heuschreckenhoden, Strahlentherapie 75 96-109, 1944.

25. Creighton, M., The effects of $\mathrm{x}$-rays on mitotic and meiotic chromosomes and cell division in Chorthippus longicornis (Orthoptera), J. Exp. Zool. 87 347-69, 1941.

26. Darlington, C. D., Recent Advances in Cytology, 2nd edit., 671 pp., Churchill, London, England, 1937.

27. Dubinin, N. P., Mechanism of Radiation Effect on Heredity and the Problem of Radiosensitivity, Proc. 2nd. U.N. Intern. Conf. Peaceful Uses Atomic Energy 22 374-82, United Nations, Geneva, Switzerland, 1958.

28. Engelmann, F., The control of reproduction in Diploptera punctata (Blattaria), Biol. Bul. 116 406-19, 1959.

29. Federley, H., Das Verhalten der Chromosomen bei der Spermatogenese der Schmetterlinge Pygaera anachoreta, curtula und pigra, sowie einiger ihrer Bastarde, Z. Abstammungsl. 9 1-110, 1913.

30. - Chromosomenzahlen finnländischer Lepidopteren, I, Rhopalocera, Hereditas $24221-69,1938$.

31. - Zytologische Untersuchungen an Mischlingen der Gattung Dicranura B. (Lepidoptera), Hereditas 29 205-54, 1943.

32. Fogg, L. C., A study of chromatin diminution in Ascaris and Ephestia, J. Morph. 50 413-52, 1930.

33. Fritz-Niggli, H., Dominant lethal factors and embryonic mortality after irradiation at $180 \mathrm{kv}$ and $31 \mathrm{Mev}$., Proc. UN Internat. Conf. Peaceful Uses Atomic Energy 11 179-83, United Nations, 1955.

34. Gatenby, J. B., The degenerate (apyrene) sperm formation of moths as an index to the inter-relationships of the various bodies in the spermatozoon, Quart.J. Micr. Sci. 62 465-88, 1917.

35. Geyer-Duszynska, I, Chromosome behavior in spermatogenesis of Cecidomyiidae (Diptera), Chromosoma 11 499-513, 1961.

36. Gilmour, D., The Biochemistry of Insects, Academic Press, New York, N. Y. and London, England, 342 pp., 1961.

37. Goldschmidt, R., Versuche zur Spermatogenese in vitro, Arch. Zellf. 14 421-50, 1917.

38. - - Kleine Beobachtungen und Ideen zur Zellenlehre. III, Die Bedeutung der atypischen Spermatozoen, Arch. Zellf. 16 291-300, 1921.

39. Grosch, D., Entomological aspects of radiation as related to genetics and physiology, Ann. Rev. Ent. 7 81-106, 1962.

40. Grünberg, K., Keim- und Nährzellen in den Hoden und Ovarien der Lepidopteren, Z. wiss. Zool. 74 327-95, 1903.

41. Heller, M., The Testis, pp. 550-97 in: Histopathology of Irradiation from External and Internal Sources, edit. W. Bloom, McGraw-Hill, New York, N.Y. U.S., 1948.

42. Hrdý, I., (editor), The Ontogeny of Insects, Acta Symp. Evol. Insect., Prague 1959, 405 pp., 1960.

43. Hughes-Schrader, S., Cytology of Coccids (Coccoidea, Homoptera), Adv. Genet. 2 127-203, 1948.

44. Huskins, C. L., Segregation and reduction in somatic tissues, I, Initial observations on Allium cepa, J. Hered. 39 310-25, 1948. 
45. Huskins, C. L., and Cheng, K. C., Segregation and reduction in somatic tissues, IV, Reductional grouping induced in Allium cepa by low temperature, $J$. Hered. 41 13-8, 1950.

46. Ichikawa, M., and Nishiitsutsuji-Uwo, J., Studies on the role of the corpus allatum in the Eri-silkworm, Philosamia cynthia ricini, Biol. Bul. 116 88-94, 1959.

47. Ingram, J. W., and Bynum, E. K., The Sugarcane Borer, Farm. Bul. No. 1884 $1-17,1941$.

48. Kernewitz, B., Úber Spermiogenese bei Lepidoptera, Zool. Anz. 46 137-9, 1915.

49. Knaben, N., Spermatogenese bei Tischeria angusticolella Dup., Z. Zellf. mikr. Anat. 13 290-323, 1931.

50. Kogure, M., and Nakajima, M., Differential Radiosensitivity of Silkworm Testis for Decline of Egg Hatchability, with Special Reference to Cytological and Biochemical Evidence, Proc. UN Inter. Conf. Peaceful Uses Atomic Energy 22 351-9, United Nations, Geneva, Switzerland, 1958.

51. Kurihara, S., On the spermatogenesis of Chilo simplex Butler, a Pyralid moth, J. Col. Agr. Imp. Univ. Tokyo 10 235-46, 1929.

52. Kvelland, I., Radiosensitivity in different stages of spermatogenesis in Drosophila melanogaster, Hereditas 48 220-42, 1962.

53. Lima-de-Faria, A., and Nordqvist, T., Disintegration of $\mathrm{H}^{3}$ labeled spermatocytes in Melanoplus differentialis, Chromosoma 13 60-6, 1962.

54. Lorković, Z., Die Chromosomenzahlen in der Spermatogenese der Tagfalter, Chromosoma 2 155-91, 1949.

55. - Chromosomen-Vervielfachung bei Schmetterlingen und ein neuer Fall fünffacher Zahl. Rev. Suisse Zool. 56 243-9, 1949.

56. Lüning, K. G., X-ray induced dominant lethals in different stages of spermatogenesis in Drosophila, Hereditas 38 91-107, 1952.

57. -, X-ray induced mutations in Drosophila melanogaster, Hereditas 38 108-9, 1952.

58. Machida, J., Eine experimentelle Untersuchung über die apyrenen Spermatozoen des Seidenspinners Bombyx mori L., Z. Zellf. mikr. A nat. 9 446-510, 1929.

59. Makino, S., An Atlas of the Chromosome Numbers in Animals, Iowa Univ. Press, Ames, Iowa, 290 pp., 1951.

60. - A Review of the Chromosome Numbers in Animals, Hokuryukan, Tokyo, Japan, pp. 400, 1956.

61. Mathur, R. S., Studies on the normal and $x$-irradiated spermatogenesis of Stenobothrus viridulus and Schistocerca gregaria (Orthoptera), La Cellule 61 173-90, 1960.

62. Mazia, D., Mitosis and the physiology of cell division, The Cell 3 77-423, 1961.

63. Metz, C. W., An apparent case of monocentric mitosis in Sciara (Diptera), Sci. 63 190-1, 1926.

64. - Chromosome behavior, inheritance and sex determination in Sciara, Amer. Nat. 72 485-520, 1938.

65. Meves, F., Utber oligopyrene und apyrene Spermien und über ihre Entstehung nach Beobachtungen an Paludina und Pygaera, Arch. mikr. Anat. 61 1-84, 1903.

66. Monesi, V., Autoradiographic study of DNA synthesis and the cell cycle in spermatogonia and spermatocytes of mouse testis using tritiated thymidine, J. Cell. Biol. 14 1-18, 1962.

67. Oakberg, E. F., Sensitivity and time of degeneration of spermatogenic cells irradiated in various stages of maturation in the mouse, Radiation Res. 2 369-91, 1955. 
68. Ohnuki, Y., Phase cinematography studies on the effects of radiation and chemicals on the cells and the chromosomes, $I$, Types of $x$-ray induced chromosome abnormalities in grasshopper spermatocytes, with a note on the normal course of the first division as control, J. Fac. Sci. Hohkaido Univ. Ser. VI, 14 83-91, 1948.

69. Oksala, T., Zytologische Studien an Odonaten, II, Die Entstehung der meiotischen Präkozität, Ann. Acad. Sci. Fenn. A IV 5 1-34, 1944.

70. - Timing relationships in mitosis and meiosis, Proc. 9th Intern. Congr. Genet. 1 272-81, 1954.

71. - The mitotic mechanism of two mouse ascites tumours, Heredilas 42 161-88, 1956.

72. Oster, I. I., Modification of x-ray mutagenesis in Drosophila, Adv. Radiobiol. 1957, 475-80, 1957.

73. Pollister, A. W., and Pollister, P. F., The relation between centriole and centromere in atypical spermatogenesis of viviparid snails, Ann. N.Y. Acad. Sci. 45 1-48, 1943.

74. Portmann, A., Die atypische Spermatogenese bei Buccinum undatum L. und Purpura lapillus L. Ein Beitrag zur Analyse des Spermiendimorphismus der Prosobranchier, Z. Zellf. mikr. Anat. 12 307-26, 1930.

75. Prescott, D. M., The growth-duplication cycle of the cell, Intern. Rev. Cytol. 11 255-82, 1961.

76. Puck, T., and Marcus, P. I., Action of x-rays on mammalian cells, J. Exp. Med. 103 653-66, 1956.

77. Regnart, H. C., Additions to our knowledge of chromosome numbers in Lepidoptera, Proc. Univ. Durham Phil. Soc. 9 79-83, 1932.

78. Ris, H., The anaphase movement of chromosomes in the spermatocytes of the grasshopper, Biol. Bul. 96 90-106, 1949.

79. Saitoh, K., Studies of sexuality and morphology in the gypsy moth, Lymantria dispar L. II, On the chromosomes of $F_{1}$ hybrids between the weak and strong races, Jap. J. Genet $3397-101,1958$.

80. - The chromosomes of some species of moths, Jap. J. Genet. 34 84-7, 1959.

81. Scharrer, B., Hormones in Insects, pp. 125-62 in: Thimann, K. V.: The Action of Hormones in Plants and Invertebrates, Academic Press, New York, N.Y., 228 pp., 1952.

82. Schrader, F., Cytological and evolutionary implications of aberrant chromosome behavior in the harlequin lobe of some Pentatomidae (Heteroptera), Chromosoma 11 103-28, 1960.

83. Smith, S. G., Chromosome numbers of Coleoptera, Heredity 7 31-48, 1953.

84. - Chromosome numbers of Coleoptera, II, Canad. J. Genet. Cytol. 2 66-88, 1960.

85. - - Cytogenetics of insects, Ann. Rev. Ent. 5 69-84, 1960.

86. Stevens, N. M., Further studies on the chromosomes of Coleoptera, J. Exp.Zool. 6 101-21, 1909.

87. Strangio, V. A., Radiosensitivity during spermatogenesis in Drosophila melanogaster, Amer. Nat. 96 145-9, 1962.

88. Suomalainen, E., The kinetochore and the bivalent structure in the Lepidoptera, Hereditas 39 88-96, 1953.

89. Taylor, E., Dynamics of spindle formation and its inhibition by chemicals, $J$. Biophys. Biochem. Cytol. 6 193-6, 1959.

90. Tinyakov, G. G., and Arsenieva, M. A., Cytogenetic Effect of Ionizing Radiation 
on Nuclei of Germ Cells of Monkeys. Proc. UN Intern. Conf. Peaceful Uses Atomic Energy 22 366-73, 1958.

91. Virkki, N., Zur Zytologie einiger Scarabaeiden (Coleoptera), Studien an der Spermatogenese, Ann. Zool. Soc. "Vanamo" 14 1-104, 1951.

92. - Mitose und Meiose, Naturwiss. Rundschau 8 352-5, 1955.

93. —-, Zur Kenntnis der postmeiotischen Ereignisse der Samenentwicklung bei den Skarabäiden (Coleoptera), Z. Zellf. mikr. Anat. 44 644-65, 1956.

94. - Chiasma relations in an elaterid beetle, Agriotes mancus Say, Proc. 10th Int. Cong. Ent. Montreal 2 953-9, 1958.

95. - Non-conjugation and late conjugation of the sex chromosomes in the beetles of the genus Alagoasa (Chrysomelidae; Alticinae), Ann. Acad. Sci. Fenn. A IV 64 1-22, 1961.

96. Wagner, H., Samen- und Eireifung der Mehlmotte Ephestia krïniella Z., Z. Zellf. mikr. Anat. 12 749-71, 1930.

97. Welshons, W. J., and Russell, W. L., The effect of x-rays on the Drosophila testis and a method for obtaining spermatogonial mutation rates, Proc. Nall. Acad. Sci. U.S. 43 608-13, 1957.

98. White, M. J. D., The evidence against polyploidy in sexually reproducing animals, Amer. Nat. 80 610-19, 1946.

99. - Animal Cytology and Evolution, 2nd ed. Cambridge Univ. Press, England, 454 pp., 1954.

100. Whiting, A., Sensitivity to $x$-rays of different meiotic stages in inlaid eggs of Habrobracon, J. Exp. Zool. 83: 249-69, 1940.

101. - Effects of x-rays on hatchability and on chromosomes of Habrobracon eggs treated in first meiotic prophase and metaphase, Amer. Nat. 79 193-227, 1945.

102. - Failure of pupation of Ephestia larvae following exposure to x-rays, Anat. Rec. 108 609, 1950.

103. Wigglesworth, V. B., The physiology of ecdysis in Rhodnius prolixus (Hemiptera), II, Factors controlling moulting and "metamorphosis", Quart. J. Micr. Sci. 77 191-222, 1934.

104. - Insect Physiology, Methuen \& Co., London, England, and Wiley \& Sons, New York, N.Y., 130 pp. 1961.

105. Wilde, J. de, Photoperiodism in insects and mites, Ann. Rev. Ent. 7 1-26, 1962.

106. Williams, C. M., part of Discussion in: Physiology of Insect Development, Univ. Chicago Press, Chicago, Ill., 167 pp., 1958.

107. - The juvenile hormone, I, Endocrine activity of the corpora allata of the adult Cecropia silkworm, Biol. Bul. 116 323-8, 1959.

108. Wilson, C. B., and K. C. Cheng, Segregation and reduction in somatic tissues, II, The separation of homologous chromosomes in Trillium species, $J$. Hered. 40 2-6, 1949.

109. Zirkle, R. E., Bloom, W., and Uretz, R. B., Use of partial-cell irradiation in studies of cell division, Proc. UN Intern. Conf. Peaceful Uses of Atomic Energy 11 273-82, 1955. 